Lexis Vol. XLIII (2) 2019: 517-559

\title{
"Non ha tan buena escuela cuemo casa de señores" El consejero caballeresco en el Libro del cavallero et del escudero de don Juan Manuel
}

\author{
Mario Cossío Olavide \\ Universidad San Ignacio de Loyola
}

\section{RESUMEN}

En este artículo analizo la figura del consejero en la primera obra didáctica de Juan Manuel, el Libro del cavallero et del escudero. Para ello establezco las relaciones entre el libro, temprano producto de su proyecto políticoliterario, y la producción de la clerecía cortesana y la clerecía aristocrática promovidas como bases de nuevos modelos cortesanos y estamentales desde el reinado de Alfonso X. Detengo mi análisis en las características que convierten al consejero en transmisor de un enciclopedismo caballeresco, unión del saber de la letradura escolástica y del saber práctico de los defensores. Propongo interpretar la figura consiliar como un mecanismo discursivo creado para sostener un nuevo proyecto de legitimidad aristocrática: la clerecía señorial.

Palabras clave: Libro del cavallero et del escudero, don Juan Manuel, consejeros, literatura consiliar, clerecía señorial 


\section{ABSTRACT}

In this article I analyze the figure of the counselor in Juan Manuel's first work, the Libro del cavallero et del escudero. To this end, I establish the relationship between the text, an early product of the author's larger literary and political project, and the literary production of the courtly and aristocratic clerecia that was promoted as the basis of new courtly models starting in the reign of Alfonso X. My analysis centers on the characteristics that converted the counselor into a transmitter of a chivalric encyclopedism which unified the knowledge of the lettered scholars and the practical know-how of defensores. I propose that this counselor figure can be interpreted as a discursive mechanism created to support a new project of lordly legitimacy: the seigneurial clerisy.

Keywords: Libro del cavallero et del escudero, Juan Manuel, counselors, advice literature; seigneurial clerisy

\section{Consejo y consejeros en las literaturas alfonsí y sanchí}

Los Castigos de Sancho IV describen así la función de los consejeros:

El buen consejero e leal e verdadero e partido de toda mala lisonja, fazerte ha que por el su consejo bueno que estés bien con Dios e que ayas graçia e amor del señor cuyo vasallo eres [...]. E consejarte ha que tomes buenas costunbres e las buenas maneras e que dexes las malas. Consejarte ha que mantengas e guardes la tu buena fama e que non cayas en la mala. E consejarte ha que te abengas bien con tu muger e la honres e la ames e la mantengas en buen estado [...]. Consejarte ha que ames los tu fijos de tal amor qual deve aver padre a fijos e a sus herederos. Consejarte ha que fagas bien la tu fazienda e que [la] llieves adelante con Dios e con derecho. Consejarte ha que bivas honradamente e non a desonra de ti. Consejarte ha que ames justiçia e que la fagas e la non vendas por dineros (2001: 251-252, 34.15). ${ }^{1}$

\footnotetext{
1 Al citar códigos legales, tratados sapienciales, teológicos y otras obras medievales capituladas y divididas en libros y secciones, indico esta información tras la referencia bibliográfica.
} 
Esta descripción es muy diferente a la exposición hecha algunas décadas antes en las Partidas sobre los consejeros. Alfonso X enfatiza la capacidad intelectual y el rol educativo de estos asesores "bien entendidos e de buen seso" ([1555] 2011c: fol. 22v, 2.9.5), aspecto resaltado mediante la presencia de sentencias atribuidas a Salomón, Aristóteles y Séneca en la misma ley; la legalidad alfonsí configura una visión del consejero centrada en su capacidad de discernimiento y de acción, describiendo un individuo capaz de identificar los peligros que acechan a sus aconsejados y apercibirlos de ellos.

Desde una discursividad marcadamente religiosa y desmontando los mecanismos articuladores del entramado alfonsí, Castigos complementa esta definición al centrarse en los efectos morales de la labor de los consejeros; su tarea es ofrecer a los reyes un sendero de ortodoxia religiosa (acciones hacia Dios) y de respeto de las relaciones estamentales (acciones a su señor). Un consejero debe educar a hombres capaces de controlar su comportamiento, tanto en la esfera pública (costumbres, buenas maneras y fama) como en la privada (familia y poridat). Todas estas características los convierten en transmisores de un conjunto de valores (honra, justicia, amor, lealtad) que permiten al hombre construir una imagen propia y participar en un orden social establecido, acatando un programa ideológico marcado por una clara ortodoxia doctrinal.

Estas visiones son evidencias de un periodo de la historia castellana medieval en el que los privados adquirieron gran relevancia como figuras para mantener el poder de los reyes y los grandes señores, según han notado recientemente Rochwert-Zuili y Thieulin-Pardo (2011: 31); esta realidad encuentra un reflejo en la producción letrada que coincide con este fenómeno. Como han estudiado Lacarra (1979: 117-120), Haro Cortés (1995: 243 y 2003: 227-228) y Gómez Redondo (1998: 206-210, 248, 273-274, 429), Alfonso X patrocinó el romanceamiento de versiones árabes de obras orientales en las que ayos y maestros son figuras centrales de la transmisión del conocimiento y reforzamiento ideológico; en este sistema cultural y político, el rey es la figura central de la corte (clerecía cortesana); esta es la tarea de Aristóteles y los filósofos 
y los sabios que aparecen en los Bocados de oro, la Poridat de las poridades y el Libro de los buenos proverbios, y los consejeros en la ficción ejemplar del Calila e Dimna. ${ }^{2}$

Los consejeros de estos libros son manifestaciones de la importancia que Alfonso cifró en la burocracia curial para guiar sus acciones y facilitar el establecimiento de un entramado social regalista que permitiera sostener sus aspiraciones al trono imperial. Sin embargo, este proyecto político falló doblemente; Alfonso no logró ocupar el trono romano y sus intentos de centralizar el poder revelaron el gran descontento que existía entre las poderosas familias de la vieja nobleza castellana por la proyección de un nuevo orden social regalista, que se tradujo en las revueltas nobiliarias de 1272 y la guerra civil de 1282 entre él y un gran sector de la nobleza aliada a su segundogénito, Sancho.

Por otra parte, los estudios de Bizzarri (1995: 46-56), Gómez Redondo (1998: 914-944), Funes (1999: 170-171) y Haro Cortés (2003: 71-75) aclaran que a partir del reinado de Sancho IV apareció un nuevo conjunto de obras consiliares que cifraban la clerecía aristocrática, una nueva propuesta de ordenamiento monárquiconobiliario. La guerra civil que marcó la transición de reinados demostró que si Sancho quería conservar su poder, y el de su linaje segundogénito, debía incorporar a la nobleza en su proyecto político. ${ }^{3}$ Sancho y su esposa, la reina María de Molina, fueron los

\footnotetext{
2 A lo largo del artículo utilizo la terminología propuesta por Fernando Gómez Redondo en su enciclopédica Historia de la prosa medieval castellana, planteamiento que resumió recientemente y que cito por su utilidad: “[en] el sistema letrado alfonsí [aparece] el modelo de clerecía cortesana-valor supremo del rey como figura central de la corte- [que en el molinismo] se sustituye por el de clerecía aristocrática-integración de la nobleza en el servicio de esa corte-" (2012: 71). A estos conceptos propongo añadir un tercer modelo de legitimidad nobiliaria que apareció a partir de la mayoridad de Alfonso XI, cifrado en el proyecto literario de Juan Manuel, cuya importancia en la vida política del reino durante la primera mitad del siglo XIV hace necesaria tal distinción. La clerecía señorial propone la revisión de los dos modelos anteriores, reivindicando el rol de la alta nobleza castellana para la construcción de la legitimidad y el poder regio. Iré definiendo las características de este proyecto a lo largo del artículo. La validez del término clerecía sobre Juan Manuel ha sido demostrada convincentemente por Funes (2007: 13-17).

3 Sobre las continuas tensiones entre la monarquía y la nobleza en las últimas décadas del siglo XIII y las primeras del siguiente, véanse Moxó (1973: 501-504) y Gómez Redondo
} 
artífices del modelo social conocido como el molinismo, mantenido tras la muerte del rey y durante las minoridades de Fernando IV y Alfonso XI por la reina María; un modelo en el que el poder regio estaba sostenido por el ordenamiento estamental aristocrático y por una discursividad ortodoxa. ${ }^{4}$

La monarquía promovió la escritura y la traducción de una serie de tratados, centrados en el consejo y los consejeros, que reemplazaban los modelos alfonsíes, aún presentes en el espacio curial. En este periodo aparecieron el Lucidario, los Castigos de Sancho IV y el Libro del consejo et de los consejeros. El modelo del consejero de estas obras, como puede observarse en la anterior cita de los Castigos, es de un asesor regio cuyo principal campo de acción es la vida espiritual y privada del aconsejado. En ellos el bien común de la sociedad no depende tanto de su capacidad de instruir a los reyes para capear las intrigas políticas o los hechos de armas que amenazan al reino, como en la clerecía cortesana, sino de transmitir estrategias para controlar el fuero interno del individuo. El campo de acción de los consejeros es moral; su tarea es ayudar a sus aconsejados a lograr una espiritualidad ejemplar sobre la que se sostiene la legitimidad de su poder terrenal. Estos principios pueden luego ser transmitidos hacia abajo en el orden estamental para asegurar su mantención. Tal estrategia explica que en este mismo periodo aparecieron varios romances hagiográficos, como el Libro del cavallero Zifar (=Zifar) y Barlaam e Josafat (=Barlaam), donde los privados son los guías espirituales y morales de sus aconsejados regios. ${ }^{5}$

\section{(2012: 46-47).}

4 Véanse Orduna (1996: 60-61) y Gómez Redondo (1998: 856-1092, 1999: 1225-1771, 2007: 4022-4031 y 2012: 49-54). Aunque el Diccionario de la Real Academia no reconoce la voz consiliar utilizo este latinismo, atestiguado en la Suma de política de Rodrigo Sánchez de Arévalo y el segundo libro del Amadis de Gaula de Garci Rodríguez de Montalvo, para referirme al género de consejos producido en los circuitos cortesanos para encauzar el comportamiento de los defensores y orientar sus relaciones con el poder monárquico. Lo empleo además porque recuerda que las obras didácticas de Juan Manuel son el producto de una de las obligaciones de la nobleza medieval, ofrecer su consilium al rey (Valdeavellano [1968] 1984: 375).

5 La clerecía aristocrática del molinismo queda perfectamente resumida en la miniatura inaugural (fol. 2r) de uno de los manuscritos de los Castigos de Sancho IV (Biblioteca 
Además de ser vehículos de propaganda e ideología, como explica Judith Fersters, los consejeros que aparecen de los tratados y los romances didácticos medievales transmiten discursos de resistencia ante modelos de gobiernos demasiado poderosos (1996: 4). Esta afirmación es verificable especialmente en los cuatro tratados didácticos compuestos por la figura más relevante de la prosa castellana del siglo XIV, don Juan, hijo del infante don Manuel. Los universos narrativos del Libro del cavallero et del escudero (=LCE), el Libro de los estados (=LE), el Libro de los enxiemplos del conde Lucanor et de Patronio (=CL) y el Libro infinido $(=L I)$ giran todos en torno de la figura articuladora del consejero. ${ }^{6}$

En cada uno de estos libros el autor introduce un nuevo maestro, siempre al servicio de las cambiantes necesidades de su proyecto político: el consejero caballeresco en el $L C E$, el consejero regio en el $L E$, el consejero nobiliario en el $C L$ y el consejero familiar en el $L I$. Cada uno de ellos condensa una alternativa nobiliaria - la clerecía señorial - a la legitimidad regia que Alfonso XI intentaba construir en los mismos años que el noble desarrolló su actividad literaria. Son los consejeros quienes desvelan los mecanismos utilizados por el autor para crear un soporte discursivo y retórico con el que podía cifrar las razones detrás de su ideología y sus acciones,

Nacional de España Ms. 3995). En la figura Sancho aparece ataviado y con regalia (espada y corona), sentado en el trono dirigiéndose a un joven mozo, Fernando IV, quien recibe sus consejos con una mano sobre el corazón. Detrás de este, una enorme cruz simboliza la ortodoxia de los consejos del rey, mensaje reiterado por la inscripción "initior sapiencie timor domini et cetera" (Salmo 110) al lado del rey. El mismo ideal de los Castigos del rey de Mentón en el Zifar: "[Zifar] entróse en su cámara con sus fijos e asentóse el rey en su siella e mandó a ellos que se asentasen antél, las caras tornadas contra él e bien, así como maestro que quiere mostrar a escolares” (1995: 315), como lo reflejan las preciosas ilustraciones del manuscrito parisiense del Zifar (Bibliothèque nationale de France, Espagnol 38). No hay visión más radicalmente opuesta que la clerecía cortesana, representada en la inicial miniada (fol. 2r) del Libro de los animales que caçan (BNE Ms. Res. 270), en la que Alfonso X está sentado en el trono, sin otro atributo que su corona, con sus brazos extendidos hacia un traductor judío que le presenta un libro. Sobre las ilustraciones de Castigos, véanse Keller y Kinkade (1984: 52-59), Bizzarri (2002: 61-63) y Haro Cortés (2014: 67-73).

6 Cito por las versiones de: $L C E$, Ayerbe-Chaux (1989); $L E$, Macpherson y Tate (1991); CL, Serés; y LI, Mota (2003). 
reflejada en este seguro espacio textual de su propia hechura. Mi propósito en las siguientes páginas es explorar la aparición de la primera figura consiliar juanmanuelina, el consejero caballeresco, y los elementos que definen esta primera iteración del pensamiento nobiliario de Juan Manuel.?

\section{Buen seso y entendimiento. El consejero caballeresco de Juan Manuel}

El Libro del cavallero et del escudero está dedicado al arzobispo de Toledo y primado de España Juan de Aragón. El libro utiliza como marco narrativo una ficción dialogada - "una manera que llaman en esta tierra fabliella” (1989: 9)—, de acuerdo con el modelo de la literatura de preguntas y respuestas medievales (quaestiones) que facilita el intercambio de conocimiento entre un maestro y su discípulo. ${ }^{8}$

La premisa de la obra es bastante simple, se trata de un relato sobre la educación de un joven escudero por un caballero anciano. Un rey ha convocado cortes a las que acuden muchos nobles y caballeros de todas partes del reino, incluyendo a un joven escudero que se queda dormido sobre su palafrén camino a la corte y se despierta en un campo frente a un ermitaño, quien resulta ser un antiguo caballero. Deseoso por compartir el conocimiento de la venerable figura, el escudero le formula una serie de preguntas sobre el mundo, su composición y la orden de caballería que este irá respondiendo en una larga exposición que ocupa la mayor parte del libro. Un primer grupo de respuestas es interrumpido cuando el escudero se encamina de nuevo a las cortes, donde es investido

\footnotetext{
7 Una segunda entrega de esta investigación titulada "Letradura, entendimiento y buen seso. El consejero regio en el Libro de los estados de Juan Manuel” aparecerá el próximo año en la Revista canadiense de estudios hispánicos

8 Sobre la relación entre el autor y Juan de Aragón, véase Tate (1977: 169-79); el significado de fabliella ha sido estudiado por Lizabe (1988: 415-417), Feito (1990: 35), Gómez Redondo (1998: 1111) y Taylor (2000: 199-200). Deyermond aclara que la fuente más cercana para Juan Manuel es el Lucidario, que también utiliza el marco de un diálogo de dos personajes, el maestro y el discípulo ([1971] 1979: 244).
} 
caballero gracias a la educación que ha obtenido. Tras retornar a su tierra, el caballero novel extraña la sabiduría de su maestro y decide volver junto a él para terminar de escuchar las respuestas irresueltas. La historia termina con la muerte del caballero anciano. ${ }^{9}$

La escritura de este libro, datado hacia 1327, coincide con el inicio de la etapa más turbulenta de la vida política del autor, periodo al que precisamente se debe la mayor parte de su obra. A partir de 1321, y durante los últimos años de la minoridad de Alfonso XI, Juan Manuel se había desempeñado como tutor del rey. Aunque había tenido que luchar por ocupar este cargo, ya que los consejos de algunas ciudades y villas se opusieron a su nombramiento, pudo mantenerlo hasta 1325; este año el rey se declaró mayor de edad y los tutores fueron forzados a dejar sus cargos. Los problemas comenzaron para Juan Manuel cuando Alfonso tomó como privados a Garcilaso de la Vega y Alvar Núñez de Osorio, personajes cercanos a otro de los antiguos tutores del rey y su enemigo, el infante Felipe.

Las acciones tomadas por estos malos consejeros para consolidar sus influencias y extender el poder regio incluyeron un plan destinado a romper la amistad de Juan Manuel y Juan el Tuerto, otro de los antiguos tutores de Alfonso. La alianza entre ambos nobles había sido fortalecida por un acuerdo de matrimonio entre Juan el Tuerto y Constanza, hija del autor. Según relata la Crónica de Alfonso XI, los consejeros idearon un plan para unir al rey y Constanza, esperando que esta propuesta creara una ruptura entre los nobles: tomando "consejo con algunos de sus consegeros [...] [el rey] falló que le convenía partir por alguna manera aquella amistad" (fol. 192r); así la corona se aseguraba la desunión de "los más poderosos omnes de su regno" (fol. 191v). ${ }^{10}$ Por intrigas de estos mismos

9 Desgraciadamente, una porción de la historia se ha perdido por la separación de dos bifolios del único testimonio que transmite este libro, el manuscrito $S$ de las obras de Juan Manuel (BNE Ms. 6376). La laguna comprende gran parte del capítulo 3 hasta el capítulo 16, reconstruidos por Taylor (1984), cuya propuesta reviso en la tabla 2, al final del artículo.

10 Cito por la versión vulgata de la Crónica de Alfonso XI del ms. 10132 de la BNE. Al requerir el matrimonio con Constanza, el rey se aseguró de que Juan el Tuerto comen- 
personajes, Juan el Tuerto fue asesinado por órdenes de Alfonso XI en Toro en 1326. Terminado el engaño, el rey dio órdenes de recluir a Constanza en el alcázar de esta ciudad en 1327 y anunció sus planes de desposarse con la infanta María de Portugal.

Estos eventos detonaron hostilidades abiertas entre Alfonso XI y Juan Manuel, doblemente humillado por la pérdida de tan valioso aliado y la prisión de su hija. Este es el contexto histórico que marca la escritura de este libro, considerado por algunos críticos una obra terapéutica (Lizabe 1988: 405), en la que el autor comienza "la teorización de los valores sociales caballerescos, con los que antes había obtenido sus más significativos logros” (Gómez Redondo 1998: 1109).

La historia de la fabliella no puede ser más diferente de estos eventos. En el capítulo 2 se describe la convivencia de un rey y la nobleza en el trasfondo de una legalidad idealizada:

[E]n una tierra avía un rey muy bueno et muy onrado, et que fazía muchas buenas obras, todas segund pertenesçía a su estado. Et por mostrar la su nobleza fazía muchas vezes sus cortes ayuntar, a que venían muchas gentes de sus tierras et de otras. Et de que estavan con él, fazíales mucho bien, dando algo de lo suyo muy granadamente a los que lo devía dar. [...] Et tanto bien les fazía, que el amor que la naturaleza dava, que todos le devían aver así como a su rey et a su señor natural [...]. Et por esta razón, plazía mucho a todos quando por ellos enbiava; et venían a él muy de grado quando los avía menester (1989: 10-11).

zara a sospechar de Juan Manuel: "Don Johan, fijo del infante don Johan, teniéndose por engañado de don Johan, fijo del infante don Manuel, porque diera al rey por muger a doña Constança, su fija, et él era a la su merçed venido, et otrosí porque el rey le diera el adelantamiento de la frontera, cató otras muchas maneras para deservir al rey, dando a entender a las gentes que por su cabo lo podía fazer sin ayuda del otro don Joha" ( 50 , fol. 193r). Para proteger la imagen de rex iustus y avalar el engaño con el que Alfonso atrae a Juan el Tuerto a Toro, Fernán Sánchez de Valladolid enumera los excesos que había cometido durante la minoridad de Alfonso, las voces que se corrían sobre sus planes de apoyar los reclamos dinásticos de Alfonso de la Cerda ("para le traer al reino con voz de rey", 50, fol. 193r) y las muchas noticias recibidas de que "catava todas las maneras que podía por alçarse contra el rey en el regno y por le fazer guerra, et que fablava en su deserviçio" (52, fol. 194r). 
La escena inicial sirve para establecer al rey como cabeza de la sociedad, que actúa dando "buenas leyes et buenos fueros et mantenía et guardávales muy bien lo que avían de los otros reys que fueron ante que él" (1989: 11, 2). Este marco narrativo tiene muchos paralelos con la clerecía cortesana que Alfonso X intentó establecer en Castilla durante el siglo XIII, según transmiten los prólogos de sus primeros corpus legales, el Fuero Real y el Espéculo. ${ }^{11}$

Tabla 1. Modelo regio de la clerecía cortesana

\begin{tabular}{|c|c|}
\hline Espéculo & Fuero Real \\
\hline $\begin{array}{l}\text { Onde conviene al rey, que a de tener } \\
\text { et guardar sus pueblos en paz, et en } \\
\text { justiçia et en derecho, que faga leys et } \\
\text { posturas por que los departimientos et } \\
\text { las voluntades de los omnes se acuerden } \\
\text { todas en uno por derecho por que los } \\
\text { buenos vivan en paz et en justiçia, et los } \\
\text { malos sean castigados de sus maldades } \\
\text { con pena de derecho (1990: } 5 \text { ). }\end{array}$ & $\begin{array}{l}\text { Onde conviene a rey, que ha a tener sus } \\
\text { pueblos en justicia e en derecho, que } \\
\text { faga leyes pora que los pueblos sepan } \\
\text { como an de bevir, e las desabenencias } \\
\text { e los pleitos que nascieren entre ellos } \\
\text { sean departidos, de manera que los que } \\
\text { mal fizieren reciban pena, e los buenos } \\
\text { bivan seguramient (1988: 184). }\end{array}$ \\
\hline
\end{tabular}

Aunque al inicio del libro el rey sirve como cabeza simbólica del reino, asegurador del "pro comunal” (Alfonso X [1555] 2011c: fol. 1r) y promulgador de leyes, con el avance de los capítulos queda claro que el lugar alrededor del cual gira el universo didáctico no es la curia regia, sino la corte señorial en la que se educó el anciano caballero. Si bien el rey es el organizador de la sociedad, desde su distancia y breve presencia en el relato, el caballero es quien posee la sabiduría. Esta modulación en el orden social del reino ficcional es la primera indicación de un alejamiento del pensamiento político del autor respecto al legado alfonsí. ${ }^{12}$

11 También de los libros sapienciales alfonsíes, como Bocados de oro: "Conviene al rey que sea la primera cosa en que comience, de mostrar las leyes que pertenescen a su pueblo" (al-Mubaššir 1971: 37, 9.79).

12 Ya lo apuntó Dunn: “The just king as imago dei could not be clearer. He is such that men are drawn to serve and to love him and willingly give their lives. He is both loved and feared. Here we see two of the attributes of God, power and love, and an effect, justice. The third attribute-wisdom and knowledge- is found in the old knight, not in the king" (1977: 57). 
Como han notado numerosos críticos desde Francisco de Paula Canalejas, el marco narrativo del libro es muy similar al Llibre de l'orde de cavalleria (= Llibre, c. 1276) de Ramon Llull, en el que un caballero ermitaño educa a un joven escudero en el arte de la caballería. Juan Manuel indica oscuramente esta fuente en el primer capítulo: "fiz este libro en que puse algunas cosas que fallé en un libro” (1989: 10) y en el segundo: “dize en el comienço de aquel libro...” (1989: 10). Pero lejos del tratamiento reverencial esperable hacia una autoridad como Llull, el autor introduce algunas críticas que defienden el mérito de su obra respecto a la del mallorquín. Explicándole el contenido a su destinatario, Juan de Aragón, dice no entender si el libro de Llull es una historia o una ficción - "et si el comienço dél es verdadero o non, yo non lo sé” (1989: 10, 1)—, apuntando a la indeterminación genérica del Llibre en comparación a la elección del género de la fabliella para su libro. También dice haber añadido nuevo contenido que merecía ser incluido: “otrosí puse ý algunas otras razones que fallé scriptas et otras algunas que yo puse, que pertenecían para ser ý puestas” (1989: 10, 1). Estos elementos prologares indican el deseo del autor de diferenciar su tratado de otras obras que circulaban en su tiempo, tanto por su estilo como por su contenido. ${ }^{13}$

La primera diferencia sustancial a nivel de contenido se encuentra en la visión de cada autor sobre el estamento de la caballería, codificada en la enseñanza de sus personajes. El caballero de Llull sostiene un enfoque fundamentalmente religioso y es muy crítico de la realidad de los caballeros aragoneses en el siglo XIII. Salvo este caballero anciano, todos los protagonistas del Llibre ignoran las leyes que rigen la caballería: "los cavaylers qui són en aquest temps no són en l’orde en lo qual eren los altres cavaylers qui foren

13 Véanse Menéndez Pelayo ([1905] 2008: 1, 139-141), Riquer (1964: 1, 252), Deyermond ([1971] 1979: 244), Devoto (1972: 243-245), Cantarino (1984: 60-61), Lizabe (1988: 402), Seniff (1992: 50) y Gómez Redondo (1998: 1111). El Llibre se inscribe en "una tradició literària i uns motius novel-lescos evidents, que provenen del roman curtois francès, probablement dels romans que anomenem del cicle del Graal' el motiu del bosc, la figura del vell cavaller que es fa ermita, l'ermità mateix, la relació cavaller-ermità, el motiu de l'escuder dormisquejant i endut pel cavall a l'atzar" (Soler 1988: 15), elementos ausentes en el LCE. 
primers [...] los cavaylers qui are són usen de l'offici de cavaylaria si són injurioses e guerrers e amadors de mal e de trebayls" (1988: 187). La solución propuesta por el consejero llulliano es aplicar las reglas de la vida monástica a la orden de caballería. En numerosos pasajes el anciano establece paralelos entre la profesión religiosa y la caballeresca derivada de una concepción estamental de la sociedad: “molts són los officis que Déus ha donats en est món a ésser servir per los hòmens; mas, tots los pus nobles, los pus honrats, los pus acostats dos officis qui sien en est món, és offici de clergue e offici de cavayler" (1988: 174).

El consejero caballeresco de Juan Manuel ofrece similares argumentos sobre el lugar de la caballería en la sociedad estamental. Afirma que "los estados del mundo son tres: oradores, defensores, labradores" (1989: 12, 17) y "como quier que entre los legos ay muchos estados, así como mercadores, menestrales et labradores, et otras muchas gentes de muchos estados, la cavallería es más noble et más onrado estado que los otros" (1989: 13, 18), reiterando la visión sacramental de la caballería presente en el Llibre, introducida en Castilla en las Partidas: "et este estado [de cavallería] non puede aver ninguno por sí, si otri non gelo da, et por esto es como manera de sacramento" (1989: 13, 18).${ }^{14}$ Esta afirmación debe, sin embargo, ser cuidadosamente considerada pues no tiene el mismo propósito que la proclamación del estado religioso de los caballeros que puede

14 También debe la visión de los tres órdenes de la sociedad a las Partidas:

Defensores son uno de los tres estados por que Dios quiso que se mantuviese el mundo. Ca bien así como los que ruegan a Dios por el pueblo son dichos oradores, e otrosí los que labran la tierra e fazen en ella aquellas cosas por que los omes han de bivir e de mantenerse son dichos labradores, otrosí los que han a defender a todos son dichos defensores [...]. [Ante] mostramos qual deve ser el pueblo a la tierra dó mora, faziendo linaje que la pueble e labrándola para aver los frutos della e enseñoreándose de las cosas que en ella fueren e defendiéndola e guardándola de los enemigos, que es cosa que conviene a todos comunalmente. Pero con todo eso, a los que más pertenesce son los cavalleros, a quien los antiguos dizen defensores... ([1555] 2011c: fols. 70r-70v, 2.21.13).

En las siguientes leyes aparece la misma visión sacramental de la caballería; la investidura caballeresca es análoga al ordenamiento sacerdotal: " $\mathrm{E}$ bien así como las órdenes de los oradores non las podría ninguno dar si non el que las ha, otro tal non ha poder de fazer ninguno cavallero si non el que lo es" ([1555] 2011c: fol. 72r, 2.21.11). El proceso de investidura es descrito en las leyes 13 y 14 del título 21 de la Segunda partida ([1555] 2011c: fols. 73r-74r). 
encontrarse en el Llibre o en otras obras de marcado cariz ortodoxo, como el Zifar. ${ }^{15}$

Juan Manuel, como Alfonso X en las Partidas, considera que los caballeros son ante todo fijosdalgo y defensores, es decir, representantes de la nobleza en general; por tanto, estas aserciones sirven para defender los derechos y la honra de la que gozan los caballeros en un orden social ideal. Lida de Malkiel (1950: 159) sostiene que la presencia del estricto esquema estamental en el $L C E$ refleja que su aplicación en la sociedad castellana de este periodo es, como mucho, dudosa; a la luz de esta consideración las afirmaciones del caballero tienen el propósito de reafirmar y defender los privilegios de la nobleza que profesa la orden de caballería, que el autor considera “el mayor et más onrado estado que es entre los legos" (1989: 13, 18). A esto también se debe la insistencia de que los hombres respeten sus estados en varias ocasiones: "ca si el omne non cognosçe su estado, nunca lo sabrá guardar; et si non lo guardare, todo su fecho traerá errado. Et los estados son de tantas maneras que lo que pertenesçe al un estado es muy dañoso al otro" $(1989: 39,38){ }^{16}$

Otra diferencia importante entre ambos libros es la forma de transmisión del conocimiento sobre la caballería y cuál es el rol del consejero caballeresco en este proceso. Al principio del Llibre, el escudero llega dormido en su palafrén y es notado por el caballero anciano, quien interrumpe su rezo y comienza a leer: "lexà sa oració e assec-se en lo bel prat, a la ombra de l'arbre, e començà a legir a.llibre que tenia en sa fauda" (1988: 163). En el primer encuentro entre ambos, y sin aún mediar palabras, Llull ya ha establecido las bases de su modelo didáctico: la oración, oratio, y la lectura, lectio.

15 O la investidura de Roboán en el reino del emperador de Triguiada en el Zifar: «En el nonbre de Dios»-dixieron los reys- «fazetlo cavallero, que fiamos por Dios que por quanto en él vemos e entendemos que tomaredes dél buen esfuerço». [...] E otro día en la mañana fue el enperador a la eglesia de Sant Johán, dó velava el infante, e oyó misa e sacólo a la puerta de la eglesia a una grant pila de porfidio que estava llena de agua caliente e feziéronle desnuyar so unos paños muy nobles de oro e metiéronlo en la pila e dávale el agua fasta en los pechos; e andavan en derredor de la pila cantando todas las donzellas e dizían: « $i$ Biva este caballero novel a servicio de Dios e a onra de su señor e de sí mesmo!» (1995: 543-544).

16 Sobre la analogía entre caballeros y defensores en las Partidas, véase Martin (2004: 220), y sobre el pensamiento estamental, Rodríguez-Velasco (1993: 69-71). 
El caballero saluda al adormecido escudero y le explica que "la regla e l'orda de cavaylaria és en aquest libre en lo qual jo lig alcunes vagades, per so que·m fassa remenbrar la gràcia e la merçè de Déus m’à feta en aquest món” (1988: 164). Tras algunas explicaciones, le entrega el libro y explica su propósito: "fet per retornar la devoció e la leyaltat e l'ordonament que cavayler deu aver en tenir son orde" (1988: 165). El aprendiz asume la tarea de su maestro; debe ir a la corte y enseñar la sabiduría del libro a los demás caballeros: "bel fil, portats-vos aquest libre a la cort hon enats e mostrars-lo a tots aquells qui volen ésser cavalers novells" (1988: 165). El resto de la historia no es sino una lectura del contenido doctrinal del libro que el escudero ha recibido y llevado a la corte, en cuyas páginas se describen los orígenes de la caballería, las características del oficio de los caballeros, su educación y la ceremonia de investidura, los principios morales y virtudes que deben poseer y cuál es el simbolismo de sus armas.

Aunque se han perdido los capítulos 3 al 16 del LCE, que corresponden al encuentro entre el escudero y el caballero anciano y la formulación de las preguntas del primero, la educación que este recibe en los capítulos restantes no se fundamenta en el modelo de lectio divina de Llull, donde prima la autoridad escrita; es un proceso que involucra la transmisión oral. En estos capítulos el caballero responde las preguntas que se hicieron en los capítulos perdidos; tal exposición permite guiar el aprendizaje de su pupilo, prestando atención a temas demasiado complicados para su poco preparada mente y resolver las confusiones que una lectura desordenada puede producir — recuérdese la desconfianza del autor a los errores de interpretación de los copistas (que son lectores, después de todo) en el Prólogo general, por los que se "muda toda la entençión et toda la sentencia” (2006: 5)—.

A pesar de que el autor codifica estos saberes mediante la escritura en sus libros, los rasgos orales de los castigos de este consejero - y de los que aparecen en sus tres siguientes tratados didácticosreflejan la realidad de la educación de los defensores en las cortes castellanas de los siglos XIII y XIV, un proceso fundamentalmente 
oral. Es conocido que Juan Manuel debe este recurso a Alfonso X y a la literatura molinista. En las Partidas se explica: ${ }^{17}$

...acostumbravan los cavalleros, quando comían, que les leyesen las estorias de los grandes fechos de armas que los otros fizieran e los sesos e los esfuerços que ovieron para saberlos vencer e acabar lo que querían. E allí dó no avían tales escrituras, fazíanlo retraer a los cavalleros buenos e ancianos, que se en ellos acertavan. E sin todo esto aún fazían más, que non consentían que los juglares dixiesen ante ellos otros cantares, sinon de guerra o que fablasen en fecho de armas. [...] E esto era porque oyéndolas les crescían las voluntades e los coraçones e esforçávanse, faziendo bien e queriendo llegar a lo que los otros fizieran o pasaran por ellos ([1555] 2011c: fol. 75r, 2.21.20).

Otro ejemplo de este comportamiento se encuentra en la descripción de la corte de Jerjes (Asuero) en el Libro de Ester de la General estoria:

El rey Asuero, non podiendo dormir, mandó adozir sus estorias et libros anales de los primeros tiempos. E leyendo antél por ellos, porque se non dormiese, estándose en vagar, segund diz [Flavio] Josefo, mas que pudiese velar por pensar en mantenimiento de sos regnados leyéndole los fechos de los reyes que fueran ante dél dond él regnava e los suyos dond tomase exiemplo cómo avíe a fazer... (Alfonso X 2011b: fol. 187v).

En el entorno cortesano en el que Juan Manuel fue educado el leer podía ser análogo al escuchar. Esta relación aparece claramente en el Zifar, cuando el infante Roboán escucha un romance artúrico, la Estoria de Yván, de una de las doncellas de la emperatriz Nobleza:

E la una donzella llevava el libro de la estoria de don Yván e començó a leer en él; e la doncella leía muy bien e muy apuestamente e muy ordenadamente, de guisa que entendía el infante muy bien todo lo

17 Un estudio clásico de este fenómeno en el contexto europeo es el de Saenger (1982: 405). Para Castilla, véanse Montoya (1991: 353-356), Orduna (1995: 134-135), Gómez Redondo (1998: 797) y Lacarra (2002: 279-280). 
que ella leía e tomava en ello muy grand placer et grant solaz; ca, certas, non ay onbre que oya la estoria de don Yván que non resciba ende muy grand plazer por las palabras muy buenas que en él dize. E todo onbre que quisiere aver solaz e plazer e aprender buenas costunbres deve leer el libro de la estoria de don Yván (Zifar 1995: $566)$.

La oralidad de las palabras de los consejeros no solo debe a estas características de la educación nobiliaria, gracias a las que Juan Manuel conoció muchos de los libros y tratados que utilizó como fuentes para sus obras; es también el resultado de cómo escribió sus libros. La composición del $L C E$, que el autor describe en el prólogo utilizando los verbos conponer y fazer — " non lo fiz porque yo cuydo que sopiese conponer ninguna obra muy sotil [...] yo la fiz poner en este libro" (1989: 9)—, fue un proceso oral; él dictaba sus palabras a un escribano, quien las copiaba y luego revisaba bajo su tutela, práctica habitual en el entorno cortesano castellano, según explica una reflexión sobre autoría en la General estoria:

El rey faze un libro non por quel él escriva con sus manos, mas porque compone las razones dél et las emienda et yegua et enderesça et muestra la manera de cómo se deven fazer, et desí escrívelas qui él manda, pero dezimos por esta razón que el rey faze el libro. Otrosí, cuando dezimos el rey faze un palacio o alguna obra, non es dicho porque lo él fiziese con sus manos, mas porquel mandó fazer et dio las cosas que fueron mester pora ello, e qui esto cumple aquel ha nombre que faze la obra, e nós así veo que usamos de lo dezir (Alfonso X 2011a: fol. 216r).

A diferencia de Alfonso X, es sabido que Juan Manuel participaba en todos los momentos de la escritura, desde el dictado hasta la revisión final (concertación) de sus manuscritos. En el proceso de composición del LCE se introdujeron y mantuvieron características de un discurso oral que el autor privilegiaba como la mejor forma de enseñar. Considero que a esto se debe la repetición constante del "oý dezir”, “oý fablar” y "oý departir” y que el anciano se dirige siempre al escudero usando fórmulas orales: "vos digo", "vos he dicho", cuya utilidad para reforzar la autoridad en el texto escrito 
es innegable, pero que adquieren verdadera relevancia al considerar cómo fue compuesto y revisado el libro, y cómo sería ejecutado oralmente tras ser publicado ( $L E$ 1991: 73, 2); este sería el momento en el que un lector o ejecutante asumiría la autoridad del caballero y castigaría con sus buenas razones a su público, trasladando la dinámica oral de consejero y aconsejado, codificada en la textualidad, a la realidad. ${ }^{18}$

Para asegurarse de lograr el efecto de autoridad y reforzar la efectividad de la lectura aural, el discurso del consejero está marcado por constantes reproches sobre las formas del razonamiento del escudero; el maestro corrige errores en la concepción de su estudiante: “A lo que me preguntastes qué cosa es cavallería et cómo la puede omne mejor conplir, fijo, esta pregunta non es una solamente. Me semejan que son tres” (1989: 14, 19), “...así como otras vegadas vos dixe, todas vuestras preguntas que me vos fazedes son dobladas, et eso mismo es en esta" $(1989: 39,38) .{ }^{19}$

El didascalismo y la oralidad del discurso del consejero caballeresco son rasgos que no desaparecen del estilo de Juan Manuel y seguirán presentes en sus libros posteriores; en ellos se cifra una concepción de la educación como una dinámica de intercambio activo de conocimiento entre un maestro y un discípulo, proceso que no existe en el Llibre, pero que es bastante más común en la prosa castellana de los siglos XIII y XIV. El conocimiento transferido

18 Juan Manuel demuestra en pocos momentos la preocupación sobre los beneficios de la recepción aural de sus obras: "Ca bien entendedes vós, señor infante, que en los tienpos apresurados de las guerras et de las lides, non puede [omne] aver vagar entonçe de bolver las fojas de los libros para estudiar con ellos. Ca, segund yo cuido, pocos omnes son que cuando se cruzan las lanças, que nol tremiese la palabra si entonçe oviere de le[e] r el libro, et siquiere en el roído de las vozes et de los colpes de la una parte et de la otra, le estorvarían tan bien el le[e]r como el oír. Et por ende, todas estas cosas aprovechan de fablar en ellas, porque puede ser que de algunas se aprovechará [omne] aviéndolo ya oído" (LE 1991: 220-221, 1.74). Pocos estudios se centran en este complejo aspecto de su obra: Seniff (1984: 95-102 y 1989: 268-269), Funes (2000: 132-133) y Lacarra (2002: 280). Sobre la "publicación”, véase Olivetto (2014: 112-117).

19 Sobre esto apunta Gómez Redondo que "el caballero anciano enseña y, a la vez, reflexiona sobre los mecanismos lógicos con que dispone su enseñanza. [...] El personaje descubre los resortes de su pensamiento y convierte en comprensibles razones la materia abstracta (sin importar su índole) que le ha sido preguntada” (1998: 1113). 
en este proceso puede ser tomado de fuentes escritas, auctoritates: "si vos quisiéredes saber todo esto que me preguntastes de la cavallería conplidamente, leed un libro que fyzo un sabio que dizen Vejeçio et ý lo fallaredes todo", pero es más habitualmente codificado en términos de la experiencia vital del sujeto: "mas lo que yo entiendo de aquel poco entendimiento que yo he, vos diré" (1989: 14, 19). La tarea del consejero caballeresco es ofrecer a su aprendiz un camino alternativo al conocimiento; sendero construido sobre el saber práctico del autor, que al mismo tiempo refuerza la visión estamental que encuadra la narración.

Por oposición, en el Llibre la educación es concebida como un proceso escolástico de lectura autónoma del saber enciclopédico (sciència scrita en libres), demostrada per letres. El caballero anciano lee su libro en silencio para perfeccionar su virtud, disciplina que transmite al escudero, a quien le encomienda llevar el libro a la corte y mostrarlo a los que quieran ser caballeros. Llull establece un esquema comunicativo con funciones bien definidas y que no admiten ampliación: hay un magister (destinador) que transmite la sapientia (mensaje) mediante el liber (contacto) al discipulus (destinatario). Este circuito es repetido, con algunas alteraciones, cuando el escudero llega a la corte: "sàviament e ordonada donà e representà aquest libre al molt noble rey e a tota la gran cort; e sofferí que tot cavayler qui am ésser en orda de cavallaria lo pusque translatar, per ço que a les vagades liga e recort l'orda de cavaylaria" (1988: 165); también aparece más adelante, en la materia contenida en el libro del caballero: ${ }^{20}$

On, si los clergues an maestra e doctrina e estan en scoles per ésser bons, e si tantes scièncias són que stan en doctrina e en letres, injúria molt gran és feyta a l'orde de cavaylaria con no és enaxí una sciència demostrada per letres e que·n sie feta scola con és de les altres sciències. On, per asyò, aquest qui compon aquest libre soplega al noble

20 La obra de Llull es un ejemplo preciso del proceso de tránsito entre la lectura aural y la lectura silenciosa que caracteriza el escolasticismo y la cultura monástica entre los siglos XII y XIV (Saenger 1982: 381-391). Adapto el clásico esquema de la comunicación verbal de Jakobson ([1963] 1975: 352-353). 
rey e a tota la cort qui és ajustada a honor de cavaylaria, que sie satisfet e restituhit a l'honrat orde de cavaylaria, qui ès agradable a Déu (1988: 170-171). ${ }^{21}$

En LCE el autor reconoce la importancia de los libros como medios de transmisión del saber:

Et otrosí [los sabios] tienen que una de las cosas que lo más acresçenta es meter en scripto las cosas que fallan, por que el saber et las buenas obras puedan ser más guardadas et más levadas adelante. Por ende yo, don Johan, fijo del infante don Manuel, fiz este libro en que puse algunas cosas que fallé en un libro (1989: 10, I).

Pero esta visión es matizada en la materia didáctica por el consejero, quien defiende la necesidad de una educación práctica que permita ejercer el saber transmitido por los maestros. La principal función del consejero juanmanuelino es personificar el saber; no es destinador, sino al mismo tiempo mensaje y contacto, encarnación de una de las facultades del alma, entendimiento, siempre guiada por el buen seso, atributo de origen divino que permite al hombre discernir. Así lo admite el aconsejado: “Ca quanto más menos leýstes et sabedes más que los otros que mucho an studiado, por vuestro entendimiento, tanto es çierto que vos fizo Dios mayor gracia en vos dar el entendimiento por que sopiésedes lo que sabedes" (1989: 24, 30).22

21 Llull también rechaza cualquier tipo de educación práctica y oral: "Enaxí com los juristes e·ls metges e ls clergues an sciència e libres, e oen la lissó e aprenen lur offici per doctrina de letres, tant és honrat e alt l'orde de cavayler, que no tant solament abasta que a l'escuder sia mostrar l'orde de cavaylaria per pensar de cavayl ni per servir senyor ni per enar ab eyl en fet d'armes ni per altres coses semblants a aquestas; que enans seria convinent cosa que hom de l'orde de cavaylaria feés scola, e que fos sciència scrita en libres e que fors art mostrada, axí con són mostrades les altres sciències; e que los infants fiyls dels cavaylers, en lo començament, que apresessen la sciència qui pertany a cavaylaria $e$, enaprés, que fossen scuders e que enassen per les letres ab los cavaylers" (1998: 170).

22 Entendimiento y buen seso son conceptos de orígenes distintos que aparecen emparejados en las letras castellanas desde el siglo XIII. Entendimiento (intelligentia) es, junto a la voluntad y la memoria, una de las facultades del alma descritas por Agustín de Hipona en De trinitate: "Haec igitur tria [sunt facultates]: memoria, intelligentia, voluntas, quoniam non sunt tres vitae, sed una vita; nec tres mentes, sed una mens; consequenter utique nec tres substantiae sunt, sed una substantia [...] Mens imago Trinitatis in sui ipsius memoria, intelligentia et voluntate” (1865: cols. 983-984, 10.11-12.18-19), que además del prólogo 
La doble naturaleza de las palabras del consejero es un rasgo bastante importante para comprender el proyecto didáctico del libro; él y su conocimiento describen dos mundos distintos, el del saber letrado (obtenido gracias a la letradura) y el del saber práctico (producto del seso natural). ${ }^{23}$ La lectura silenciosa y la instrucción escrita no son tan importantes como la capacidad de discernir los saberes y aplicarlos a situaciones reales, alineando el programa del libro con el modelo educativo del molinismo. Ya los Castigos de Sancho IV advierten: "Del seso viene el entendimiento, e de la razón viene el conosçimiento" (2001: 280, 39), mientras que el Zifar sostiene que la letradura no sirve si no puede ser escrutada por el buen seso:

E por ende, dizen que más val una onça de letradura con buen seso natural que un quintal de letradura sin buen seso; ca la letradura faze al onbre orgulloso e sobervio e el buen seso fázelo omildoso e paciente. E todos los onbres de buen seso pueden llegar a grant estado, e mayormente seyendo letrados e aprendiendo buenas costunbres, ca en la letradura puede onbre saber quáles son las cosas que deve usar e quáles son de las que se deve guardar [...]; ca estas dos cosas, seso e letradura, mantienen el mundo en justicia e en verdat e en caridat (Zifar 1995: 368). ${ }^{24}$

del Zifar, aparece en el prólogo del Libro de buen amor: "tres cosas, las quales dizen algunos doctores philósophos que son en el alma e propiamente suyas [...]: entendimiento, voluntad e memoria" (3-5). Juan Manuel tiene el mérito de ser el primer autor lego que lo introduce en su discurso, posiblemente por influencia de los frailes predicadores conectados con su scriptorium. El buen seso natural es una de las facultades dadas por Dios al hombre para juzgar lo que aprende por su entendimiento o lo que sabe por su memoria, y ponerlo a buen uso. En Zifar: "Onde, bienaventurado es aquel a quien Dios quiere dar buen seso natural, ca más val que letradura muy grande para saberse onbre mantener en este mundo e ganar el otro" (1995: 368). Sobre las implicaciones de este concepto y su historia en la literatura del periodo, véanse Cacho Blecua (1996: 126), Parrack (2006: 278-89), Rochwert-Zuili (2011: 8) y Gómez Redondo (2013: 285).

${ }^{23}$ Además de ser conocimiento proveniente de las ciencias, la letradura "se inscribe en una concepción general de la cortesía que, en este período, debe ser regulada por la ética aristotélica o la sçiencia de buenas costumbres [...] requiriendo una producción letrada que permita verificar y difundir esa materia con un contenido básicamente moral y religioso" (Gómez Redondo 2012: 72).

${ }_{24}$ También: "E comoquier que la ciencia sepa onbre de coraçón e la reze, sin buen seso natural non la puede onbre bien aprender e aunque la entienda, menguado el buen seso 
Por este motivo el caballero anciano se declara incapaz de responder las preguntas del escudero mediante "palabras señaladas" (1989: 25, 31), esto es, el lenguaje técnico de los escolares. No posee el vocabulario de científicos y filósofos, los “omnes sabidores" (Alfonso X 1988: 185) con quienes Alfonso X armó su corte y codificó su pensamiento. ${ }^{25}$ Más bien, aboga por la introducción de elementos prácticos en la educación de los defensores:

Et como quier que yo nunca leý nin aprendí ninguna sçiençia, porque só mucho ançiano et guareçí en casa de muchos señores, oý departir a muchos omnes sabios. Et bien cred que para los legos non ha tan buena escuela en el mundo cuemo criarse omne et bevir en casa de los señores; ca ý se ayuntan muchos [omnes] buenos et muchos sabios, et el que ha sabor de aprender cosas por que vala más, en ningún lugar non las puede mejor aprender (1989: 25, 31).

Tal alejamiento de la clerecía cortesana no significa que Juan Manuel adopta completamente las bases de la educación aristocrática molinista, proyecto que revisa el ideario alfonsí. Aunque $L C E$ introduce cierto contenido doctrinal cristiano, pues el orden estamental se sustenta sobre el orden divino, las acciones del consejero caballeresco y sus palabras están enfocadas a transmitir a su aprendiz información y una forma de razonar que le permitirá, ante todo, defender su estado. El autor descarta la sujeción absoluta a la justicia y la verdad, valores caballerescos y regalistas defendidos por el molinismo, y a los principios de la ortodoxia religiosa que caracterizan este pensamiento. Surge, en cambio, una fuerte conciencia de la posición social del individuo, de su estado, alejado de la corte regia donde se educaba a los nobles.

natural, non puede obrar della nin usar así como conviene a la ciencia de qual parte quier que sea" (Zifar 1995: 22).

25 Esta es una nueva humilitas del consejero (y del autor), como apuntan Scholberg (1959: 24-26) y Rico (1986: 414). Sin embargo, debe notarse que las palabras señaladas del caballero remiten a las disciplinas privilegiadas en el proyecto cultural alfonsí: “oý fablar a omnes muy letrados en muchas sciençias, et oýlos dezir que por las cosas que son ordenadas en aquella arte, dizen los gramáticos reglas; et por lo que llaman los gramáticos reglas, dizen los lógicos máximas, et llaman los físicos anphorismas. Et lo mismo en todas las sciencias” (1989: 25, 31). 
Estas alteraciones de la figura consiliar tienen una implicación evidente: Juan Manuel está reevaluando la importancia de los lugares de transmisión del conocimiento en su época. Descartados los espacios monástico-clericales, los studia de la clerecía cortesana alfonsí y las scholas de la clerecía aristocrática molinista, se propone una nueva ubicación de la cultura, en la que el caballero anciano fue educado y que marca la educación del escudero: la corte señorial. Esta es una de muchas transformaciones ideológicas propuestas por el $L C E$, que dejan claro que "la clerecía, a pesar de su sapiencia, no es indispensable en la educación del ser humano” (Durán 1994: 39) y especialmente en la de los defensores. Este desplazamiento se manifiesta en la contradictoria relación entre las preguntas del escudero y las respuestas ofrecidas por su maestro. ${ }^{26}$

Todos los capítulos didácticos tienen la misma estructura: (1) el consejero reitera la pregunta del escudero y la divide en varias partes; (2) ofrece un excurso sobre una materia no relacionada con la pregunta; y finalmente, y muy brevemente, (3) responde de acuerdo con el nuevo orden propuesto. Las preguntas pueden ser divididas en cinco grandes grupos: justicia divina (1-2), estados (3-5), caballería (6-10), orden divino y de la creación (11-22) y orden natural (23-42). Es claro, además, que todas apuntan a un tipo de letradura, definiendo dos grandes temas que preocupan al escudero: la filosofía natural (1-2,11-42) y el pensamiento estamental (3-10).

Esta última división aclara cuáles son las fuentes utilizadas por el autor y cómo las adjudica al consejero y al aconsejado para representar visiones distintas sobre qué tipos de saber son necesarios para la educación de los defensores. Las preguntas de filosofía natural provienen de una de las grandes enciclopedias del siglo XIII, el Speculum naturale del dominico Vicente de Beauvais, mientras

26 Esta discusión fuerza a revisitar los planteamientos hechos por Diego Catalán (1977: 50-51) sobre la relación entre Juan Manuel y el modelo cultural alfonsí, y plantear que la sustitución de tal "aplastante legado" sucedió mucho más gradualmente de lo que se había considerado hasta ahora. 
que las de pensamiento estamental corresponden con temas codificados en las Partidas de Alfonso X. ${ }^{27}$

Para las respuestas el consejero utiliza una amalgama de fuentes, algunas de las cuales que no se ajustan a la ortodoxia desde la que el escudero hace sus preguntas - aunque en un guiño religioso, incluye en el capítulo 38 contenido del Tractatus brevis de articulus fidei compuesto por Juan de Aragón- ${ }^{28}$ Las respuestas del pensamiento estamental vienen de las Partidas, mientras que las respuestas de filosofía natural provienen de los tratados científicos alfonsíes, manifestaciones del aristotelismo heterodoxo que fue condenado y depurado por el molinismo. ${ }^{29} \mathrm{El}$ autor va más allá e introduce su

27 La correspondencia entre la obra de Beauvais y el libro fue notada por Ayerbe-Chaux en su edición de Cinco tratados de Juan Manuel (1989: XXIII), aunque no ha vuelto a ser discutida. Se altera el orden de los libros del Speculum sustancialmente. La correspondencia libros y preguntas es la siguiente: 1/11-12, 2/13-20, 5/39-40, 6/41-42, 7/37-38, 8/35-36, 9-11/31-32, 12-14/33-34, 16/27-28, 17/29-30, 18-19/25-26 y 23/23-24; y con las Partidas: $1.1 .10-12$ y $2.10 .1-3 / 2-3$ y $2.21 / 4-7$.

28 Tate (1977: 175-176) notó la coincidencia entre el Tractatus brevis de articulus fidei, sacramentis ecclesie, preceptis decalogi, virtutibus et viciis (publicado por Lomax 1972: 225-233). Debe añadirse que Juan Manuel lo pudo conocer mediante las constituciones sinodales del Concilio de Toledo (1323), en las que es incorporado como primer canon (publicadas por Tejada y Ramiro 1849: 3, 505-518), ya que utiliza la estructura de los siguientes cánones en la composición del $L E$.

${ }_{29}$ En $L C E$ : “...en los [çielos] avía siete estrellas et el sol et la luna et otras çinco; et estas siete que andan de oriente a ocçidente, así como las otras estrellas. Et esto es porque las lieva el çielo en que andan todas las estrellas” (1989: 38, 37). Scholberg (1959: 30) apunta que quizá el sistema de organización celestial de las esferas y el primum mobile ptolemaico debió ser conocido por Juan Manuel por las obras de Alfonso X. Viene, específicamente, del Libro de la ochava esfera, primera parte del Libro del saber de la astrología: "el movimiento de todos los cielos que se mueven et de las estrellas que son en ellos. Tanbién de las del viii cielo, a que llaman fixas porque non han movimiento así como las otras, bien como de las otras vii a que llaman planetas por que son movedizas en sí mismas. Et otrosí por los cielos en que ellas están que se mueven siempre” (2011d: fol. 1v). También sucede esto con las constelaciones. En LCE: "Mas, las otras estrellas [que] lieva el çielo [...] son las que se non mueven et son puestas a semejança et en nonbre de algunas cosas a que semejan por la calidat que ha en ellas; et son casas et posadas de las otras planetas por que, quando llegan a ellas, se faga en las cosas de yuso dellas segund la virtud et el poder que Dios puso en ellas" (1989: 38,37), que corresponde con el segundo libro del Libro de la ochava esfera y el prólogo al Libro que fizo Aristótiles sobre las imágenes de los doze signos, del Libro de astromagia (1992: 226). Aunque el Lucidario transmite información similar, también incluye una advertencia sobre las contradicciones entre el conocimiento de la natura y del orden divino (1968: 79) y los intentos de integrar 
experiencia vital en el pequeño tratado zoológico formado por los capítulos 40 a 42, hechura propia y reflejo de la mentalidad militar con la que los defensores entendían el mundo; esta sección clasifica a los animales de acuerdo a su naturaleza de cazadores o presas: “...las aves son de muchas maneras. Unas ay que caçan et otras ay que son caçadas” $(1989: 50,41) .{ }^{30}$

Así, mientras las preguntas del escudero provienen del pensamiento escolástico y la legislación estamental alfonsí, donde el orden social es un reflejo del orden divino, una forma de organización conceptual que se mantiene aún en el molinismo, las respuestas del consejero se originan en un mucho más heterogéneo entramado textual. Vienen de una colección de obras y hechos concretos que no reflejan el esperable ascenso desde lo material hacia lo divino sostenido en el molinismo - piénsese en el recorrido de la caballería maldita a la divina en Zifar o la progresión de príncipe a asceta en Barlaam - El aprendiz desea adquirir un conocimiento siguiendo el orden establecido por las grandes enciclopedias naturales y sociales; su maestro, que sabe más, se rehúsa sistemáticamente a satisfacer esta necesidad. Para ello se refugia en protestationes y bumilitas:

Mas, esta pregunta que me fazedes: qué cosa son los alementos et para qué fueron fechos, bien entendedes vos que sería muy grant marabilla si yo pudiese a ella responder conplidamente; ca esto pertenesçía a omne muy letrado, ca esto es sçiençia et muy sotil et muy grave de fablar en ella omne por su entendimiento. Pero segund lo poco que yo entiendo... (1989: 35,36$)$.

Apelando a la experiencia vital, la bumilitas permite a personaje y autor revisar el orden social; justifica también los errores de sus palabras, atribuyéndolos a una educación informal y a menguados entendimientos. Se trata del mismo tipo de protestatio con el que

el orden celestial a la providencia divina (1968: 95-96), ortodoxa lectura que Juan Manuel no repite.

${ }^{30}$ Bizzarri demuestra que el criterio y la forma de clasificación de los animales en estos capítulos no corresponden con ningún bestiario o enciclopedia natural medieval, sino a la visión estamental de un defensor (2014: 47-49). 
Juan Manuel escuda su ambicioso proyecto literario en el Prólogo general: "non pongan la culpa a la mi entención, ca [...] buena la ove, mas pónganla a la mengua del mi entendimiento" (2006: 6). ${ }^{31}$

Entre preguntas y respuestas, el consejero introduce excursos, largas disquisiciones sin conexión aparente con los temas tocados en las que puede colar el conocimiento que realmente desea transmitir. Añade así a las funciones de su consejero — fuente de letradura y de experiencia práctica-, la de ser un guía para que el aconsejado pueda comprender su lugar como defensor en la sociedad estamental y las formas en las que debe guardar para mantener $y$, de ser posible, mejorar su condición. ${ }^{32}$

Los excursos se sostienen sobre una base sapiencial, pues deben muchos de los temas a los tratados alfonsíes y molinistas de ciencia política, saberes interpretados y reproducidos desde la mentalidad señorial de Juan Manuel. Los excursos tocan las formas de la justicia divina y los estados de los defensores (1-4), de la inteligencia y del conocimiento (5-14), los consejos y los consejeros (15 y 17), maneras de los hombres (16, 18-21), de los defensores y la justicia nobiliaria (22-25). Existe una muy general correspondencia entre las preguntas y los excursos. Las primeras diez preguntas giran sobre el orden estamental que corresponde con los primeros nueve excursos. Las preguntas sobre filosofía natural, descritas mediante un descenso expositivo desde temas divinos hasta los naturales, corresponden con los restantes, que tratan de las formas que toma el conocimiento humano, los consejos y las formas de actuar de acuerdo al estado al que el individuo pertenece. ${ }^{33}$

\footnotetext{
31 Apunta Biaggini que la reiteración de las protestationes de los personajes y del autor también reflejan "un déficit de légitimité en tant que lettré [qui] [...] tentent d'asseoir son entreprise littéraire : face aux savoirs cléricaux, essentiellement liés à la langue latine, l'œuvre en roman de Don Juan Manuel appartient nécessairement à une catégorie plus modeste" (2009: 15).

32 Cuya importancia ha sido notada por Stefano (1962: 346-7) y Gómez Redondo (1998: 1113-4).

33 Lizabe cree que Juan Manuel utiliza "la creación como elemento estructurador para su $L C E$ porque ella reflejaba el orden y equilibrio de los que carecía la realidad humana que lo rodeaba” (1988: 493).
} 
Preguntas y excursos definen un panorama análogo. Las preguntas van de Dios, a los reyes, a los defensores y terminan con la naturaleza (animales, plantas, piedras); los excursos van de la justicia como valor caballeresco, al conocimiento, a los integrantes del estamento de los defensores y terminan con las características de cada manera de defensor. Con esta organización discursiva, el autor hace énfasis en las materias prácticas hacia las que confluyen todas sus explicaciones. El discurso del consejero caballeresco sigue un sendero que lo lleva desde temas universales y complejos, característicos de los escolares, a temas cotidianos en los que es capaz de extenderse más, pues corresponden a su estado. ${ }^{34}$

Esta organización obedece a que la obra refleja un momento temprano del proyecto político-literario del autor, en el que el estilo y los mecanismos de composición y organización textual no están dominados — debiendo mucho aún a sus influencias-; también tiene que ver aquí el direccionamiento del libro. No se trata de una obra centrada en los estamentos superiores de los defensores, rico omnes o "nobles defensores" como los llama en el LE (1991: $277,1.92)$, pues que gira sobre un hombre proveniente de las filas de los "fijosdalgo o omnes onrados, criados de los señores" (LI 2003: $157,11)$, que logra convertirse durante la historia en un caballero de baja categoría. ${ }^{35}$

Es sostenible que los orígenes de los personajes no son arbitrarios; mientras el consejero es un caballero anciano educado en las casas y cortes de los grandes señores, el aconsejado es un escudero cuya historia es completamente desconocida — tanto por la pérdida de folios del texto como por el desinterés del autor de profundizar

34 Esta situación cambiará en el $L E$ y el $C L$, donde las materias se organizan en un orden de menor a mayor complejidad y oscuridad, a lo cual Gimeno Casalduero llama un "movimiento ascendente gracias a la intensificación de los elementos doctrinales" (1975: 101-102).

35 Rodríguez-Velasco indica que el orden estamental tiene características propias en la obra de Juan Manuel, quien diferencia entre nobles defensores — desde los emperadores hasta los hidalgos - y los "defensores que non son fijos dalgo" o caballeros villanos (2009: 66). Sobre estos últimos en la obra de Juan Manuel, véanse Maravall (1966: 763), Stefano (1966: 143-4) y Diz (1984: 78). 
en su historia en lo restante-. Estos elementos caracterológicos pueden ser indicativos de un momento social en el que la vieja nobleza castellana comienza a compartir rangos y privilegios con una emergente clase villana ascendida durante los reinados de Sancho IV, Fernando IV y Alfonso XI, reyes que necesitaban desesperadamente de la legitimidad obtenida con la lealtad de los rangos bajos de los defensores. En los capítulos centrales del libro (24 a 26) el escudero es investido caballero por el buen rey, quien "tanto se pagó de las sus buenas maneras quel tovo consigo grant pieça de tienpo et fízol cavallero et después enbíolo a su tierra muy rico et muy onrado" (1989: 20,24). Al volver a su tierra, el caballero novel disfruta de su nueva condición: “fue muy bien reçebido de todas las gentes [...]. Ca la bienandança et el poder et la riqueza fazen ser a omne más amado et más preçiado de las gentes” (1989: 21, 26).

Sin descartar los méritos de esta lectura no explorada, considero que el tema central del libro es la creación de un nuevo modelo de consejero afín a los intereses de la alta nobleza castellana y no supeditado al poder regio, figura desconocida en Castilla hasta ese momento. A la concentración del poder regio intentada por sucesivos monarcas desde Alfonso X le acompañó un aparato propagandístico ejemplificado en obras de temática consiliar. En el Lucidario, los Castigos, Barlaam y Zifar, los consejeros son figuras al servicio del establecimiento y la mantención del poder de los reyes; por lo general, ofrecen estas obras ofrecen dos tipos de consejeros: hombres espirituales y de moral indisputable o seres traidores que ven en sus posiciones formas de obtener prebendas. Si bien estas obras están dirigidas también a la nobleza, lo hacen para sujetarla a un conjunto de ideas, de virtudes y de comportamientos que emanan desde el trono. No debe sorprender que muchos malos consejeros en ellas son precisamente nobles que actúan contra el interés de sus señores y velando por los propios. En el Zifar, los nobles del reino, viéndose desplazados como consejeros del emperador por el infante Roboán, complotan para asesinarlo, pues se sienten "astragados [...] e desonrados, ca el enperador non nos precia nada, e así nin abremos la onra e el pro que solíemos aver” (1995: 560). 
Juan Manuel reacciona ante este intento de sujeción y ante las figuras de los defensores traidores al convertir a su primer consejero en un ejemplo de una nueva ética caballeresca. El saber del caballero está informado por la producción cultural de Alfonso X y Sancho IV, y por ello valora la educación como elemento eje de cualquier programa político; eso sí, reajusta el fundamento teórico del conocimiento de los “omnes sabios [...] e omnes muy letrados" (1989: 25, 31) de la clerecía cortesana y la clerecía aristocrática, al que añade el suyo propio, de cuña práctica, producto de su experiencia como defensor ocupado en las tareas de repoblamiento y defensa del reino. También genera un espacio de reivindicación de los derechos de los grandes señores, evidenciado por la elevación de la corte señorial al mismo rango que la curia regia: "bien cred que [...] non ha tan buena escuela en el mundo cuemo criarse omne et bevir en casa de los señores" (1989: 25, 31).

En una inversión de roles en el penúltimo capítulo del libro el consejero le pide al caballero novel que le explique cómo logra discernir la mejor forma de actuar si vive distraído por los muchos problemas derivados de mantener sus heredades y su estado. Este le responde que resuelve precavidamente las contiendas con otros nobles, emprendiéndolas solo si sabe que saldrá victorioso; trata ordenadamente los asuntos de sus rentas, sin dejar de prestar atención a unas por otras. Añade finalmente: "Et en las cosas que ove a fazer de algunas sçiençias o de algunos libros o de algunas estorias, esto finca de lo del tienpo que avía a dormir" (1989: 69, 5). Palabras finales que revelan que la educación de su maestro le han permitido guiar, además de sus actuaciones externas con las que gana experiencia práctica, aquellas internas e intelectuales que están encaminadas a satisfacer ese deseo de comprender la letradura que sus preguntas revelaban.

Esta respuesta vuelve sobre el prólogo del libro, donde el autor le explica a Juan de Aragón:

Hermano, señor: el cuydado es una de las cosas que más faze al omne perder el dormir; et esto acaesçe a mí tantas vezes que me enbarga mucho a la salud del cuerpo. Et por ende, cada vez que 
só en algún cuydado, fago que me lean algunos libros o algunas estorias por sacar aquel cuydado del coraçón. Et acaeçióme ogaño, seyendo en Sevilla, que muchas vezes non podía dormir pensando en algunas cosas en que yo cuydava que serviría a Dios muy granadamente [...]. Et seyendo en aquel cuydado, por lo perder, començé este libro que vos envío (1989: 9).

El caballero novel ocupa la misma posición que el autor en el prólogo, haciéndose leer historias para entretenerse y aprender, ¿quizá utilizando también el tiempo furtado en componer obras que sean útiles a él y a otros? En la actitud creadora del caballero novel, reflejo de lo propuesto en el prólogo, se resume el principal propósito del primer consejero creado por Juan Manuel, establecer los cimientos de un modelo de educación nobiliaria, independiente de la corte, con la que pueda sostener su condición. ${ }^{36}$

36 Además de la lectura aural cortesana, la lectura o audición en cama es un tópico habitual en este periodo, que en Juan Manuel tiene asociaciones con la vigilia creativa, según han estudiado Maravall (1965: 14-5), Taylor (2000: 190) y Funes (2007: 16). 
Tabla 2 . Estructura y reconstrucción de los capítulos perdidos del $L C E^{37}$

\begin{tabular}{|c|c|c|}
\hline & Pregunta/Evento & Excurso \\
\hline Prólogo & \multicolumn{2}{|c|}{ Dedicatoria a Juan de Aragón. } \\
\hline 1 & \multicolumn{2}{|c|}{ Incipit (“Porque dizen todos los sabios...”, LCE 1989: 10). } \\
\hline 2 & \multicolumn{2}{|c|}{ Marco narrativo: rey que convoca cortes. } \\
\hline 3 (parcial) & \multicolumn{2}{|c|}{$\begin{array}{l}\text { "Cómo un escudero salió de su tierra et yva a las cortes del buen rey por } \\
\text { ser cavallero. Et cómo se adormeçió en el palafrén que yva, por el trabajo } \\
\text { del camino..." (LCE 1989: 11). }\end{array}$} \\
\hline (4) & \multicolumn{2}{|c|}{$\begin{array}{l}\text { (Encuentro entre el escudero y caballero anciano. Presentación del } \\
\text { ermitaño). }\end{array}$} \\
\hline (5) & \multicolumn{2}{|c|}{$\begin{array}{l}\text { (Explicación de los hechos de la vida del caballero anciano y razón de su } \\
\text { retiro del mundo: “Et lo primero comiença en la emienda que el omne } \\
\text { deve fazer a Dios por sus yerros...”, LE 1991: 271). }\end{array}$} \\
\hline$(\dot{6} 6-7 ?)$ & \multicolumn{2}{|c|}{$\begin{array}{l}\text { (Caballero anciano discute la importancia de los consejos: “...et qué pro ha } \\
\text { en demandar consejo, et quánto bien ha en la humildat...”, } L E \text { 1991: 271). }\end{array}$} \\
\hline$(\dot{8} 8)$ & \multicolumn{2}{|c|}{$\begin{array}{l}\text { (Intervención del escudero, preguntas sobre la vida del caballero } \\
\text { anciano). }\end{array}$} \\
\hline (9) & \multicolumn{2}{|c|}{$\begin{array}{l}\text { (Respuesta del caballero anciano. Elogio de la caballería y de la vida } \\
\text { retirada: “...et cómo es grant vergüença dexar omne la cosa que ha } \\
\text { començada por mengua o por miedo, et cómo lo deve omne catar ante } \\
\text { que lo comiençe, et que non deve omne aventurar lo çierto por lo dub- } \\
\text { doso...”, } L E \text { 1991: 271). }\end{array}$} \\
\hline$(10)$ & \multicolumn{2}{|c|}{$\begin{array}{l}\text { (Continuación: “...et que onra et biçio non en una morada biven, et que } \\
\text { nunca se cobra el tienpo perdido...”, LE 1991: 271). }\end{array}$} \\
\hline$(11)$ & \multicolumn{2}{|c|}{$\begin{array}{l}\text { (Invitación del caballero anciano a las preguntas del escudero: “...et } \\
\text { cómo es aprovechoso el preguntar, et que deven ser las preguntas de } \\
\text { buenas cosas aprovechosas...”, } L E \text { 1991: 271). }\end{array}$} \\
\hline (12- & \multicolumn{2}{|c|}{$\begin{array}{l}\text { (Preguntas del escudero: “...et que en lo que omne quiere aprender o } \\
\text { ganar deve començar en lo que más le cunple, et que non ay bien sin } \\
\text { galardón, nin mal sin pena...”, } L E \text { 1991: 271). }\end{array}$} \\
\hline (14) & \multicolumn{2}{|c|}{ Pregunta 1: “¿Qué cosa es Dios...?” (LCE, 1989: 26). } \\
\hline
\end{tabular}

37 Realizo la interpolación de los capítulos perdidos en base a la enumeración de preguntas hecha por el caballero anciano en el capítulo 31 y a una extensa descripción de la estructura de este libro en el $L E$. También los utilizo para establecer correspondencias con los capítulos restantes y definir el ámbito de las respuestas y los excursos del consejero caballeresco. 


\begin{tabular}{|c|c|c|}
\hline & Pregunta/Evento & Excurso \\
\hline$(15)$ & $\begin{array}{l}\text { Pregunta 2: “ ¿...et por qué } \\
\text { consiente que los buenos ayan } \\
\text { mucho mal et los malos mucho } \\
\text { bien...?? (LCE 1989: 26). }\end{array}$ & $\begin{array}{l}\text { (Excurso 1. Justicia divina: “... } \\
\text { et de los juizios de Dios, et de la } \\
\text { buena andança de los malos que non } \\
\text { pueden mucho durar nin aver buena } \\
\text { fin...”, LE 1991: 271). }\end{array}$ \\
\hline 16 (parcial) & $\begin{array}{l}\text { Pregunta 3: “¿...et quáles son } \\
\text { las cosas que el rey deve fazer } \\
\text { para que sea buen rey et que } \\
\text { mantenga bien a sí et a su regno } \\
\text { et a su estado?” (LCE 1989: 26). }\end{array}$ & $\begin{array}{l}\text { (Excurso 2. Reyes: “...et qué lugar } \\
\text { tienen los reys en la tierra, et para } \\
\text { ser buenos reys, que deven fazer } \\
\text { tres cosas...”, } L E \text { 1991: 271). }\end{array}$ \\
\hline 17 & $\begin{array}{l}\text { Pregunta 4: “¿Quál es el más } \\
\text { alto estado et más onrado a que } \\
\text { los omnes pueden llegar en este } \\
\text { mundo?” (LCE 1989: 12). }\end{array}$ & Excurso 3. Religiosos \\
\hline 18 & $\begin{array}{l}\text { Pregunta 5: “¿Quál es el más } \\
\text { onrado estado entre los legos?” } \\
(L C E \text { 1989: 13). }\end{array}$ & $\begin{array}{l}\text { Excurso 4. Fijosdalgo: “...et qué } \\
\text { la cavallería que es manera de } \\
\text { sacramento...” (LE 1991: 271). }\end{array}$ \\
\hline 19 & $\begin{array}{l}\text { Preguntas 6, } 7 \text { y 8: “¿Qué cosa } \\
\text { es cavallería et cómo la puede } \\
\text { omne mejor conplir?” ( } L C E \\
\text { 1989: 14), “...et cómo se deve } \\
\text { guardar...”( } L E \text { 1991: 271). }\end{array}$ & $\begin{array}{l}\text { Excurso 5. Inteligencia: “...et qué } \\
\text { cosa es franqueza et desgastamiento, } \\
\text { et escaçeza et avareza...” (LE 1991: } \\
\text { 271). }\end{array}$ \\
\hline 20 & $\begin{array}{l}\text { Pregunta 9: “¿Quál [...] es el } \\
\text { mayor pesar que omne podría } \\
\text { aver?” (LCE 1989: 17), “...et de } \\
\text { los plazeres et de los pesares...” } \\
(L E \text { 1991: 271). }\end{array}$ & \multirow{2}{*}{$\begin{array}{l}\text { Excursos 6-7. Voluntad y razón: } \\
\text { “...et de la voluntad et de la } \\
\text { razón...” (LE 1991: 271). } \\
\text { Excursos 8-9. Gracia divina: “... } \\
\text { et cómo es conplida la graçia de } \\
\text { Dios o por qué la pierde omne...” } \\
\text { (LE 1991: 272). }\end{array}$} \\
\hline 21 & $\begin{array}{l}\text { Pregunta 10: “¿Quál era el } \\
\text { mayor plazer?” (LCE 1989: 18), } \\
\text { “...et de los plazeres et de los } \\
\text { pesares...”(LE 1991: 271). }\end{array}$ & \\
\hline 22 & \multicolumn{2}{|c|}{$\begin{array}{l}\text { Fin de las respuestas que corresponden al conocimiento general del } \\
\text { mundo y al estado del escudero: “...et qué cosas se deven catar en el } \\
\text { consejo que omne da...” ( } L E \text { 1991: 272). }\end{array}$} \\
\hline 23 & \multicolumn{2}{|c|}{$\begin{array}{l}\text { El escudero se encamina a la corte: “...et cómo deve omne gradeçer el } \\
\text { bien fecho que recibe...” ( } L E \text { 1991: 272). }\end{array}$} \\
\hline 24 & \multicolumn{2}{|c|}{ Retorno a las cortes e investidura del escudero. } \\
\hline 25 & \multicolumn{2}{|c|}{ El caballero novel visita al caballero anciano. } \\
\hline 26 & \multicolumn{2}{|c|}{$\begin{array}{l}\text { El caballero novel vuelve a su tierra y recibe honores; comienza a extrañar } \\
\text { a su maestro: “...et que el amor de la naturaleza de la tierra engaña a los } \\
\text { omnes, et que la riqueza et la buena andança, en quanto dura, faze a los } \\
\text { omnes más onrados de su derecho...” ( } L E \text { 1991: 272). }\end{array}$} \\
\hline
\end{tabular}




\begin{tabular}{|c|c|c|}
\hline & Pregunta/Evento & Excurso \\
\hline 27 & \multicolumn{2}{|c|}{ El caballero novel vuelve junto al caballero anciano. } \\
\hline 28 & \multicolumn{2}{|c|}{$\begin{array}{l}\text { El caballero novel pide las respuestas restantes: “...et del conosçimiento } \\
\text { et del desconosçimiento...” ( } L E \text { 1991: 272). }\end{array}$} \\
\hline 29 & \multicolumn{2}{|c|}{ Primera excusatio del caballero anciano. } \\
\hline 30 & \multicolumn{2}{|l|}{ Insistencia del caballero novel. } \\
\hline 31 & \multicolumn{2}{|c|}{$\begin{array}{l}\text { Segunda excusatio, explicación de la educación del caballero anciano: “... } \\
\text { et cómo deve omne dezir sus palabras con razón, et que cada sciençia ha } \\
\text { de sí palabras señaladas, et que los palaçios de los señores son escuela de } \\
\text { los fijos dalgo...” ( } L E \text { 1991: 272). }\end{array}$} \\
\hline 32 & $\begin{array}{l}\text { Preguntas } 11 \text { y 12: “¿Qué cosa } \\
\text { son los ángeles et para qué fueron } \\
\text { fechos et criados?” (LCE 1989: } \\
\text { 26). }\end{array}$ & $\begin{array}{l}\text { Excurso 10. Excusatio y asuntos } \\
\text { espirituales: “...et que los sesos } \\
\text { corporales entienden algo de los } \\
\text { spirituales..." (LE 1991: 272). }\end{array}$ \\
\hline 33 & $\begin{array}{l}\text { Preguntas } 13 \text { y 14: “¿Qué cosa } \\
\text { es el Paraýso et para qué fue } \\
\text { fecho...?” (LCE 1989: 27). }\end{array}$ & $\begin{array}{l}\text { Excurso 11. Vicios: “...et cómo es } \\
\text { malo el rebato et la pereza...” ( } L E \\
\text { 1991: 272). }\end{array}$ \\
\hline 34 & $\begin{array}{l}\text { Preguntas } 15 \text { y 16: “¿...et eso } \\
\text { mismo el Infierno?” (LCE 1989: } \\
\text { 64). }\end{array}$ & $\begin{array}{l}\text { Excurso 12. Engaños del diablo: } \\
\text { “...et cómo non deven los legos } \\
\text { escodriñar mucho en los fechos de } \\
\text { Dios...” (LE 1991: 272). }\end{array}$ \\
\hline 35 & $\begin{array}{l}\text { Preguntas } 17 \text { y 18: “¿Qué cosa } \\
\text { son los çielos et para qué fueron } \\
\text { fechos?” (LCE 1989: } 30) \text {. }\end{array}$ & $\begin{array}{l}\text { Excurso } 13 . \text { Comportamientos } \\
\text { humanos: “...et qué cosa es esfuerço } \\
\text { et quexa et miedo et spanto...” (LE } \\
\text { 1991: 272). }\end{array}$ \\
\hline 36 & $\begin{array}{l}\text { Preguntas } 19 \text { y 20: “¿Qué cosa } \\
\text { son los aelementos et para qué } \\
\text { fueron fechos?” (LCE 1989: 34). }\end{array}$ & $\begin{array}{l}\text { Excurso 14. Acciones humanas: } \\
\text { “...et cómo enpeçe entender las } \\
\text { cosas someramente, et que todas } \\
\text { las cosas se fazen por una de quatro } \\
\text { maneras..." (LE 1991: 272). }\end{array}$ \\
\hline 37 & $\begin{array}{l}\text { Preguntas } 21 \text { y 22: “¿Qué cosa } \\
\text { son las planetas et las otras } \\
\text { estrellas et para qué fueron } \\
\text { fechas?” (LCE 1989: 36). }\end{array}$ & $\begin{array}{l}\text { Excurso 15. Ayos y consejeros de } \\
\text { los mozos nobles: “...et quánto } \\
\text { grant yerro es fazer omne daño de } \\
\text { su señor por conplir su voluntad, et } \\
\text { quáles deven seer los que crían los } \\
\text { fijos de los grandes señores...” ( } L E \\
\text { 1991: 272). }\end{array}$ \\
\hline
\end{tabular}




\begin{tabular}{|c|c|c|}
\hline & Pregunta/Evento & Excurso \\
\hline 38 & $\begin{array}{l}\text { Preguntas } 23 \text { y 24: “¿Qué cosa es } \\
\text { el omne et para qué fue fecho?” } \\
(L C E \text { 1989: } 39) .\end{array}$ & $\begin{array}{l}\text { Excurso 16. Estados de los hom- } \\
\text { bres: “...et que el omne es grave } \\
\text { cosa de conosçer, et cómo omne } \\
\text { deve requerir en sí mismo sus obras } \\
\text { de cadaldía, et quáles son los artí- } \\
\text { culos de la fe, et los sacramentos de } \\
\text { la Ecclesia, et los mandamientos de } \\
\text { la ley, et las obras de misericordia, } \\
\text { et los pecados mortales, et cómo } \\
\text { omne deve buscar el más entendido } \\
\text { confesor que pudiere, et cómo omne } \\
\text { deve pensar en las cosas spirituales, } \\
\text { en guisa que non dexe las tenporales, } \\
\text { et qué cosas deve fazer por que Dios } \\
\text { le aya merçet..." (LE 1991: 272- } \\
273 \text { ), intercalado con material del } \\
\text { Tractatus brevis de articulus fidei de } \\
\text { Juan de Aragón, teorías del hombre } \\
\text { como animal racional, microcosmos } \\
\text { y árbol trastornado (invertido). }\end{array}$ \\
\hline 39 & $\begin{array}{l}\text { El anciano caballero reprocha al } \\
\text { caballero novel por la forma de } \\
\text { sus preguntas. }\end{array}$ & $\begin{array}{l}\text { Excurso 17. El buen consejo: “...et } \\
\text { cómo son en grant peligro los fijos } \\
\text { de los grandes señores, si les mengua } \\
\text { buen consejo quando salen de la } \\
\text { moçedad et entran en la mançebía, et } \\
\text { quáles son las obras del buen amigo, } \\
\text { et quáles del amigo postizo” ( } L E \\
\text { 1991: } 273 \text { ). }\end{array}$ \\
\hline 40 & $\begin{array}{l}\text { Preguntas } 25 \text { y 26: “¿Qué son } \\
\text { las bestias }[\ldots] \text { et para qué fue } \\
\text { fecho?” }(L C E \text { 1989: 46). }\end{array}$ & Tratado zoológico (montería). \\
\hline 41 & $\begin{array}{l}\text { Preguntas } 27 \text { y 28: “¿Qué cosa } \\
\text { son las aves et para qué fueron } \\
\text { fechas?” (LCE 1989: 49). }\end{array}$ & $\begin{array}{l}\text { Excurso 18. La voluntad: “...et que las } \\
\text { más cosas se fazen por voluntad, et que } \\
\text { non cunple solamente las palabras, do es } \\
\text { menester la obra...” ( } L E \text { 1991: 273) y } \\
\text { tratado zoológico (cetrería). }\end{array}$ \\
\hline 42 & $\begin{array}{l}\text { Preguntas } 29 \text { y 30: “¿Qué cosa } \\
\text { son los pescados et para qué } \\
\text { fueron fechos?” ( } L C E \text { 1989: 54). }\end{array}$ & $\begin{array}{l}\text { Excurso 19. La cordura: “...et } \\
\text { quántas maneras ay de cordura, } \\
\text { et quántas en mengua de } \\
\text { entendimiento..." ( } L E \text { 1991: 273). } \\
\text { Tratado zoológico. }\end{array}$ \\
\hline 43 & $\begin{array}{l}\text { Pregunta } 31 \text { y 32: “¿Qué cosa } \\
\text { son las yerbas et para qué fueron } \\
\text { fechas?” (LCE 1989: 55). }\end{array}$ & $\begin{array}{l}\text { Protestatio: desconocimiento del } \\
\text { caballero anciano sobre las ciencias. }\end{array}$ \\
\hline
\end{tabular}




\begin{tabular}{|c|c|c|}
\hline & Pregunta/Evento & Excurso \\
\hline 44 & $\begin{array}{l}\text { Preguntas } 33 \text { y 34: “¿Qué cosa } \\
\text { son los árboles et para qué fueron } \\
\text { fechos?” (LCE 1989: 56). }\end{array}$ & $\begin{array}{l}\text { Excurso 20. Tipos de hombres según } \\
\text { necesidad: “...et que el menester faze } \\
\text { al omne sabidor, et que por dicho de } \\
\text { las gentes non deve dexar de fazer su } \\
\text { pro, si non faze desaguisado...” ( } L E \\
\text { 1991: 273). }\end{array}$ \\
\hline 45 & $\begin{array}{l}\text { Preguntas } 35 \text { y 36: “¿Qué cosa } \\
\text { son las piedras et para qué fueron } \\
\text { fechas?” (LCE 1989: 58) }\end{array}$ & $\begin{array}{l}\text { Excurso 21. Tipos de hombres según } \\
\text { estado: “...et qué mala cosa es en fiar } \\
\text { en agüeros nin en adevinanças, et } \\
\text { cómo es bien aprovecharse omne de } \\
\text { las buenas obras” ( } L E \text { 1991: 273). }\end{array}$ \\
\hline 46 & $\begin{array}{l}\text { Preguntas } 37 \text { y 38: “¿Qué cosa } \\
\text { son los metales et para qué fueron } \\
\text { fechos?” (LCE 1989: 61). }\end{array}$ & $\begin{array}{l}\text { Excurso 22. Caballeros: “...et que } \\
\text { se deve omne bengar si ha reçebido } \\
\text { desonra, et por quáles cosas aluenga } \\
\text { Dios al omne la vida, et quántas } \\
\text { maneras son de muerte...” ( } L E \text { 1991: } \\
\text { 273). }\end{array}$ \\
\hline 47 & $\begin{array}{l}\text { Preguntas } 39 \text { y } 40: \text { “Qué cosa } \\
\text { es la mar et para qué fue fecha?” } \\
(L C E \text { 1989: 64). }\end{array}$ & $\begin{array}{l}\text { Excurso 23. Grandes señores: “... } \\
\text { et cómo los grandes señores son } \\
\text { conparados a la mar, et por quáles } \\
\text { razones...” (LE 1991: 273). }\end{array}$ \\
\hline 48 & $\begin{array}{l}\text { Preguntas } 41 \text { y } 42: \text { “Qué cosa } \\
\text { es la tierra et para que fue fecha?” } \\
(L C E \text { 1989: 65). }\end{array}$ & $\begin{array}{l}\text { Excurso 25. Justicia de los (reyes } \\
\text { y) grandes señores: “...et qué } \\
\text { departimiento ha entre los juizios de } \\
\text { los señores et de los juezes, et quáles } \\
\text { cosas deven librar los señores por sí, et } \\
\text { quáles acomendar a otro, et que non } \\
\text { deve omne començar tantas cosas que } \\
\text { enbarguen las unas a las otras, et qué } \\
\text { non deve omne comiençe la obra cate } \\
\text { recabdo para la acabar...” ( } L E \text { 1991: } \\
\text { 273). }\end{array}$ \\
\hline 49 & \multicolumn{2}{|c|}{ Fin de las preguntas del caballero anciano y pregunta al caballero novel. } \\
\hline 50 & \multicolumn{2}{|l|}{ Respuesta del caballero novel. } \\
\hline 51 & \multicolumn{2}{|c|}{$\begin{array}{l}\text { Epílogo. Muerte del caballero anciano (“...et qué tanto et más deve omne } \\
\text { fazer por su amigo en la muerte que en la vida, et que sin dubda Dios } \\
\text { galardona a los buenos et a los leales por el bien et la lealtad que fazen”, } \\
L E \text { 1991: 273-274). }\end{array}$} \\
\hline
\end{tabular}




\section{Referencias bibliográficas}

Fuentes primarias

ANÓNIMO

1995 Libro del caballero Zifar. Ed., José Manuel Lucía Megías. Tesis doctoral. Universidad de Alcalá de Henares.

Agustín de Hipona

1865 “De trinitate”. En Patrologia latina. Vol. 42. Sancti Aurelii Augustini Hiponensis Episcopi Opera omnia post Lovaniensium theologorum recensionem. Tomus octavus. Ed., Jacques Paul Mignecol. París: Vrayet, cols. 819-1098.

AL-Mubaššir IBn FĀTIK, Abū al-Wafā'

1971 Bocados de oro. Kritische Ausgabe des altspanischen Textes. Ed., Mechthild Crombach. Bonn: Universität Bonn.

Alfonso X

1988 Leyes de Alfonso X. Vol. 2. Fuero Real. Ed., Gonzalo Martínez Diez. Ávila: Fundación Sánchez Albornoz.

1990 Espéculo. Texto jurídico atribuido al rey de Castilla don Alfonso X, el sabio. Ed., Robert A. MacDonald. Madison: Hispanic Seminary of Medieval Studies.

1992 Astromagia. Ed., Alfonso D’Agostino. Nápoles: Liguori.

2011a "General estoria I". En Obras en prosa de Alfonso X el sabio. Digital Library of Old Spanish Texts. Eds., Lloyd Kasten, John Nitti y Wilhemina Jonxis-Henkemans. Madison: Hispanic Seminary of Medieval Studies. Consultado: 6 de marzo de 2019. <www.hispanicseminary.org/t\&c/ac/docs/txt-ge1. htm $>$.

2011b “General estoria IV”. En Obras en prosa de Alfonso X el sabio. Digital Library of Old Spanish Texts. Eds., Lloyd Kasten, John Nitti y Wilhemina Jonxis-Henkemans. Madison: Hispanic Seminary of Medieval Studies. Consultado: 2 de enero de 2019. $<$ www.hispanicseminary.org/t\&c/ac/docs/txt-ge4.htm $>$.

[1555] 2011c Las Siete Partidas del sabio rey don Alonso, nuevamente glosadas por el licenciado Gregorio López del Consejo Real de Indias de su Magestad. 7 vols. Ed., Gregorio López. Madrid: Andrea de Portonaris [3 vols. Madrid: Agencia Estatal Boletín Oficial del Estado]. 
2011d "Libro del saber de la astrología". En Obras en prosa de Alfonso X el sabio. Digital Library of Old Spanish Texts. Eds., Lloyd Kasten, John Nitti y Wilhemina Jonxis-Henkemans. Madison: Hispanic Seminary of Medieval Studies. Consultado: 12 de enero de 2019. <www.hispanicseminary.org/t\&c/ ac/docs/txt-ast.htm>.

s/f Libro de los animales que caçan. Biblioteca Nacional de España. Ms. Res. 270.

Beauvais, Vicente de

[1624] 1964 Speculum quadruplex sive Speculum maius. 4 vol. Graz: Akademische Druck-u. Verlagsanstalt.

JuAn MANUel

1989 Cinco tratados. Libro del cavallero et del escudero. Libro de las tres razones. Libro enfenido. Tractado de la asunçión de la Virgen. Libro de la caça. Ed., Reinaldo Ayerbe-Chaux. Madison: Hispanic Seminary of Medieval Studies.

1991 Libro de los estados. Ed., Ian Macpherson y Robert Brian Tate. Madrid: Castalia.

2003 Libro infinido. Ed., Carlos Mota. Madrid: Cátedra.

2006 El conde Lucanor. Ed., Guillermo Serés. Barcelona: Círculo de Lectores.

JuAn RuIZ (Arcipreste de Hita)

1988 Libro de buen amor. Ed., Gerald Burney Gybbon-Monypenny. Madrid: Castalia.

Llull, Ramon

1988 Llibre de l'orde de cavalleria. Ed., Albert Soler i Llopart. Barcelona: Barcino.

Lomax, Derek William

1972 "El catecismo de Albornoz". Studia albornotiana, 11, 215-233.

SÁnchez de Valladolid, Fernán

s/f Crónica de Alfonso XI. Ms. 10132, Biblioteca Nacional de España, fols. 165r-389v.

SANCHO IV (scriptorium de)

1968 Los 'Iucidarios' españoles. Ed., Richard Paisley Kinkade. Madrid: Gredos. 
Castigos del rey don Sancho IV. Ed., Hugo Óscar Bizzarri. Madrid: Iberoamericana.

Tejada y Ramiro, Juan

1849-1862 Colección de cánones y de todos los concilios de la iglesia de España y de América. 6 vols. Madrid: Imprenta de D. Pedro Montero.

Fuentes secundarias

Biaggini, Oliver

2009 "Stratégies du texte hétérogène dans le Conde Lucanor de don Juan Manuel”. Atalaya. Revue d'études médiévales romanes. 11. Consultado 12 de marzo de 2019. <doi:10.4000/atalaya.377>.

Bizzarri, Hugo Óscar

1995 "Las colecciones sapienciales castellanas en el proceso de reafirmación del poder monárquico (siglos XII y XIV)". Cabiers de linguistique hispanique médiévale. 20, 35-73. https://doi. org/10.3406/cehm.1995.931

2002 "Del texto a la imagen. Representaciones iconográficas de la realeza en un manuscrito de los Castigos del rey don Sancho IV (Ms. BN Madrid 3995)”. Incipit. 22, 53-94. https://doi. org/10.31819/9783964564924

2014 “Don Juan Manuel, fabulista”. Voz y letra. 25, 1-2, 41-51.

Cacho Blecua, Juan Manuel

1996 "Los castigos y la educación de Garfín y Roboán en el Libro del caballero Zifar". En Nunca fue pena mayor. Estudios de literatura española en bomenaje a Brian Dutton. Eds., Ana Menéndez Collera y Victoriano Roncero López. Cuenca: Universidad de Castilla-La Mancha, 117-135.

CANTARINo, Vicente

1984 “Más allá de El conde Lucanor. Un infante desconocido”. En Josep Maria Solà-Solé. Homage, bomenaje, homenatge. Vol. 1. Ed., Antonio Torres-Alcalá. Barcelona: Puvill Libros, 55-66.

Catalán, Diego

1977 “Don Juan Manuel ante el modelo alfonsí. El testimonio de la Crónica abreviada". En Juan Manuel Studies. Ed., Ian Macpherson. Londres: Tamesis, 17-51. 
Devoto, Daniel

1972 Introducción al estudio de don Juan Manuel y en particular de El conde Lucanor. Una bibliografía. Madrid: Castalia.

Deyermond, Alan

[1971] 1979 Historia de la literatura española. Vol. 1. La edad media. Barcelona: Ariel.

Diz, Marta Ana

1984 Patronio y Lucanor. La lectura inteligente 'en el tiempo que es turbio'. Potomac: Scripta Humanistica.

DunN, Peter Norman.

1977 "The Structures of Didacticism. Private Myths and Public Fictions". En Juan Manuel Studies. Ed., Ian Macpherson. Londres: Tamesis, 53-67.

DURÁN, Javier

1994

"La transformación del concepto caballeresco en tres textos medievales. Libro de la orden de caballería, Libro del cavallero et del escudero y El Victorial. Crónica de don Pero Niño". En Literature and Society. Centers and Margins. Selected Proceedings from the Second Columbia University Graduate Conference on Spanish and Portuguese Literatures. Ed., José García. Nueva York: Columbia University Press, 35-48.

FEITO, Ruth

1990 "Manera, doctrina y autoridad en el Libro del canallero et del escudero". Revista de lengua y literatura. 8, 33-39.

FERSTER, Judith

1996 Fictions of Advice. The Literature and Politics of Counsel in Late Medieval England. Pennsylvania: University of Pennsylvania Press. https://doi.org/10.9783/9781512805529

FUnEs, Leonardo

1999 "El surgimiento de la prosa narrativa en Castilla. Un enfoque histórico-cultural". En Studia Hispanica Medievalia IV. Actas de las $V$ Jornadas internacionales de literatura española medieval. Eds., Azucena Adelina Fraboschi, Clara I. Stramiello de Bocchio y Alejandra Rosarossa. Buenos Aires: Pontificia Universidad Católica Argentina, 162-171. 
2000

"Paradojas de la voluntad de autoría en la obra de don Juan Manuel”. En Actas del XIII Congreso de la Asociación internacional de hispanistas. Vol. 1. Eds., Florencio Sevilla y Carlos Alvar. Madrid: Castalia, 126-133.

2007 "Excentricidad y descentramiento en la figura autoral de don Juan Manuel”. eHumanista. 9, 1-19.

Gimeno Casalduero, Joaquín

1975 "El Conde Lucanor. Composición y significado". Nueva revista de filología hispánica. 24, 101-112. https://doi. org/10.24201/nrfh.v24i1.458

Gómez Redondo, Fernando

1998 Historia de la prosa medieval castellana. Vol. 1. La creación del discurso prosístico. El entramado cortesano. Madrid: Cátedra.

1999 Historia de la prosa medieval castellana. Vol. 2. El desarrollo de los géneros. La ficción caballeresca y el orden religioso. Madrid: Cátedra.

2007 Historia de la prosa medieval castellana. Vol. 4. El reinado de Enrique IV: el final de la Edad Media. Madrid: Cátedra.

2012 "El molinismo. Un sistema de pensamiento letrado (12841350)". En Estudios de literatura medieval. 25 años de la Asociación Hispánica de Literatura Medieval. Eds., Antonia Martínez Pérez y Ana Luisa Baquero Escudero. Murcia: Universidad de Murcia, 43-73.

2013 "El Libro del caballero Zifar. El modelo de la ficción molinista". En Uno de los buenos del reino. Homenaje al profesor Fernando D. Carmona. Eds., Carlos Alvar, Francisco José Flores y Antonia Martínez Pérez. San Millán de la Cogolla: Cilengua, 277-306.

Haro Cortés, Marta

1995 Los compendios de castigos del siglo XIII. Técnicas narrativas y contenido ético. Valencia: Universitat de València.

2003 Literatura de castigos en la Edad Media. Libros y colecciones de sentencias. Madrid: Laberinto.

2014 La iconografía del poder real. El códice miniado de los Castigos de Sancho IV. Alcalá de Henares: Universidad de Alcalá.

JAKOBSON, Roman

[1963] 1975 "Lingüística y poética”. Ensayos de lingüística general. Trad., Josep Maria Pujol y Jem Cabanes. Barcelona: Seix Barral, 347-395. 
Keller, John Esten y Richard Paisley Kinkade

1984 Iconography in Medieval Spanish Literature. Lexington: University Press of Kentucky.

Lacarra, María Jesús

1979 Cuentística medieval en España. Los orígenes. Zaragoza: Universidad de Zaragoza.

2002 "Algunos cuentos de El conde Lucanor y sus paralelos folclóricos”. En Il racconto nel medioevo romanzo. Ed., Carlos Alvar. Boloña: Pàtron, 277-297.

Lida de Malkiel, María Rosa

1950 “Tres notas sobre don Juan Manuel”. Romance Philology. 42, 3, 155-194.

LizABE, Gladys Isabel

1988 "Don Juan Manuel y la tradición de los tratados de caballería. El Libro del cavallero et del escudero en su contexto". Tesis doctoral. Syracuse University.

Maravall, José Antonio

1965 "El intelectual y el poder. Arranque de una actitud histórica". Cuadernos del idioma. 1, 3, 5-25.

1966 "La sociedad estamental castellana y la obra de don Juan Manuel”. Cuadernos hispanoamericanos. 66, 751-768.

MARTin, Georges

2004 "Control regio de la violencia nobiliaria. La caballería según Alfonso X de Castilla. Comentario al título XXI de la Segunda partida". Annexes des Cabiers de linguistique et de civilisation hispaniques médiévales. 16, 219-234. https://doi.org/10.3406/ cehm.2004.1317

Menéndez Pelayo, Marcelino

[1905] 2008 Orígenes de la novela. 2 vols. Madrid: Gredos.

Montoya MarTínez, Jesús

1991 "La doctrina de la caballería. Título XXI". En Partida Segunda de Alfonso X el Sabio. Manuscrito 12794 de la Biblioteca Nacional. Eds., Aurora Juárez Blanquer y Antonio Rubio Flores. Granada: Impresidur, 333-356. 
Moxó, Salvador de

1973 "La nobleza castellana en el siglo XIV". En La investigación de la historia hispánica del siglo XIV. Problemas y cuestiones. Madrid: Consejo Superior de Investigaciones Científicas, 493-511.

Olivetto, Georgina

2014 "Don Juan Manuel. Autor y autoeditor". Voz y letra. 25, 1-2, 111-132.

Orduna, Germán

1995 "La coexistencia de la cultura oral y producción literaria. Un nuevo enfoque en el estudio de la literatura española medieval". En Studia Hispanica Medievalia III. Eds., Lía Noemí Uriarte Rebaudi, Eric Woodfin Naylor y Joseph Thomas Snow. Buenos Aires: Pontificia Universidad Católica Argentina, 128-136.

1996 "La élite intelectual de la escuela catedralicia de Toledo y la literatura en época de Sancho IV". En La literatura en la época de Sancho IV. Eds., Carlos Alvar y José Manuel Lucía Megías. Alcalá de Henares: Universidad de Alcalá, 53-62.

PARRACK, John Cyrus

2006 "The Cultural Authority of buen seso (natural) in the Libro del caballero Zifar”. La Corónica. 35, 1, 277-291. https://doi. org/10.1353/cor.2006.0035

Rico, Francisco

1986 "Crítica del texto y modelos de cultura en el Prólogo general de don Juan Manuel." En Studia in honorem profesor Martín de Riquer. Vol. 1. Ed., Carlos Alvar. Barcelona: Quaderns Cremà, 409-423.

RiQuer, Martín de

1964 Història de la literatura catalana. 3 vols. Barcelona: Ariel.

Rochwert-Zuili, Patricia

2011 "El valor del consejo en el Libro del caballero Zifar". e-Spania.

12. Consultado: 15 de febrero de 2019. <doi:10.4000/espania.20706>.

Rochwert-Zuili, Patricia y Hélène Thieulin-Pardo

2011 "Conseil, conseillers et consiellères dans la péninsule Ibérique au Moyen Âge. Introduction”. e-Spania. 12. Consultado: 15 de febrero de 2019. <doi:10.4000/e-spania.20921>. 
Rodríguez-Velasco, Jesús

1993 "De oficio a estado. La caballería entre el Espéculo y las Siete Partidas". Cabiers de linguistique hispanique médiévale. 18-19, 49-77. https://doi.org/10.3406/cehm.1993.1082

2009 Ciudadanía, soberanía monárquica y caballería. Poética de la orden de caballlería. Madrid: Akal.

SAENGER, Paul

1982 "Silent Reading. Its Impact on Late Medieval Script and Society". Viator. 13, 367-414. https://doi.org/10.1484/J. VIATOR.2.301476

SCHOLberG, Kenneth Ray

1959 "Modestia y orgullo. Una nota sobre don Juan Manuel". Hispania. 42, 1, 24-31. https://doi.org/10.2307/334690

SenifF, Dennis Paul

1984 "Asífiz yo de lo que oý. Orality, Authority, and Experience in Juan Manuel's Libro de la caza, Libro infinido, and Libro de las armas". En Josep Maria Solà-Solé. Homage, homenaje, homenatge. Vol. 1. Ed., Antonio Torres-Alcalá. Barcelona: Puvill Libros, 91-109.

1989 "Aproximación a la oralidad y textualidad en la prosa castellana medieval". En Actas del IX Congreso de la Asociación Internacional de Hispanistas. Fráncfort: Vervuert, 263-277. https://doi.org/10.31819/9783964562180-025

1992 Antología de la literatura hispánica medieval. Madrid: Gredos.

STEFANO, Luciana de

1962 "La sociedad estamental en las obras de Don Juan Manuel". Nueva revista de filología hispánica. 16, 3-4, 329-54. https:// doi.org/10.24201/nrfh.v16i3/4.1444

1966 La sociedad estamental de la Baja Edad Media española a la luz de la literatura de la época. Caracas: Universidad Central de Venezuela.

1982 “Don Juan Manuel y el pensamiento medieval”. En Don Juan Manuel. VII centenario. Murcia: Universidad de Murcia, 337351.

TATE, Robert Brian

1977 "The Infante don Juan of Aragon and don Juan Manuel”. Juan Manuel Studies. Ed., Ian Macpherson. Londres: Tamesis, 169-179. 
TAYLOR, Barry

1984 "Los capítulos perdidos del Livro del cavallero et del escudero y el Livro de la cavallería". Incipit. 4, 51-69.

2000 "La fabliella de don Juan Manuel". Revista de poética medieval. 4, 187-200.

Valdeavellano, Luis García de

[1968] 1984 Curso de historia de las instituciones españolas. De los orígenes a la Edad Media. Madrid: Alianza Editorial.

Recepción: 01/04/2019

Aceptación: 12/11/2019 